\title{
The effect of optimistic attributional style training on self-efficacy of normal and dyslexic boys
}

\author{
Elham Eskandari ${ }^{1}$, Shole Amiri ${ }^{* *}$ iD, Amir Ghamarani ${ }^{3}$
}

1. MA in Clinical Psychology, Department of Psychology, Faculty of Education and Psychology, University of Isfahan, Isfahan, Iran

2. Professor of Department of Psychology, Faculty of Education and Psychology, University of Isfahan, Isfahan, Iran

3. Assistant Professor of Department of Children with Special Needs, Faculty of Education and Psychology, University of Isfahan, Isfahan, Iran

Recieved: 3 Apr. 2019

Revised: 19 Feb. 2020

Accepted: 19 Jun. 2020

\section{Keywords}

Optimistic attributional style training

\section{Self-efficacy}

Dyslexic boys

\section{Corresponding author}

Shole Amiri, Professor of Department of Psychology, Faculty of Education and Psychology, University of Isfahan, Isfahan, Iran

Email: S.amiri@edu.ui.ac.ir

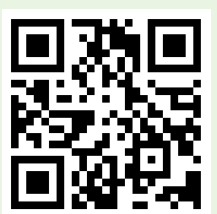

\section{Abstract}

Introduction: Self-efficacy is one of the most important cognitive abilities in which defect leads to failure. The purpose of this study was to investigate the effect of optimistic attribution style training on self-efficacy of normal and dyslexic boys of fourth grade in Isfahan city.

Methods: The study design was experimental with pre-test, post-test, follow-up and control group. After screening based on Cattell's Intelligence Test (1973), Seligman's Children Attribution Style Questionnaire (1984), Bazrafshan Moghadam Dyslexia Checklist (1997) and Kormi Nouri and Moradi Reading and Dyslexia test (2005), from the population of fourth grade male students in Isfahan city, 60 students were selected in a multi-stage random manner. Thirty normal students were randomly assigned to the experimental and control groups and 30 dyslexic students were randomly assigned to the experimental and control groups. After performing a pre-test including bandura's self-efficacy questionnaire (2006) and presenting the optimistic attributional style training, post-test and follow-up test were performed.

Results: The results of the analysis of variance with repeated measures showed that optimistic attribution style training was effective on the general self-efficacy and social skills and emotional reactions subscales of the experimental groups in post-test and one-month follow-up test $(\mathrm{P}<0.05)$. This training was effective on the academic self-efficacy of the normal experimental group and the reading self-efficacy of the experimental dyslexic group in both post-test and follow up $(\mathrm{P}<0.05)$, but it was not effective on the reading self-efficacy of the normal experimental group and the academic self-efficacy of the experimental dyslexic group in post-test and follow up $(\mathrm{P}>0.05)$.

Conclusion: Optimistic attribution style training can improve normal and dyslexic boys' self-efficacy, and this program can be used to improve children's self-efficacy.

Citation: Eskandari E, Amiri Sh, Ghamarani A. The effect of optimistic attributional style training on self-efficacy of normal and dyslexic boys. Advances in Cognitive Sciences. 2020;22(3):123-136. 


\title{
تاثير آموزش سبك اسناد خوشبينانه بر خودكار آمدى پسران عادى و نار ساخوان
}

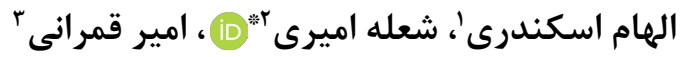

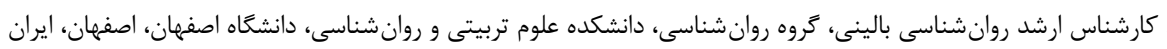

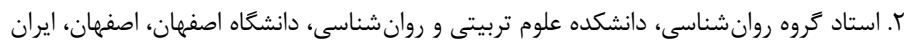

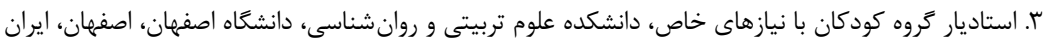

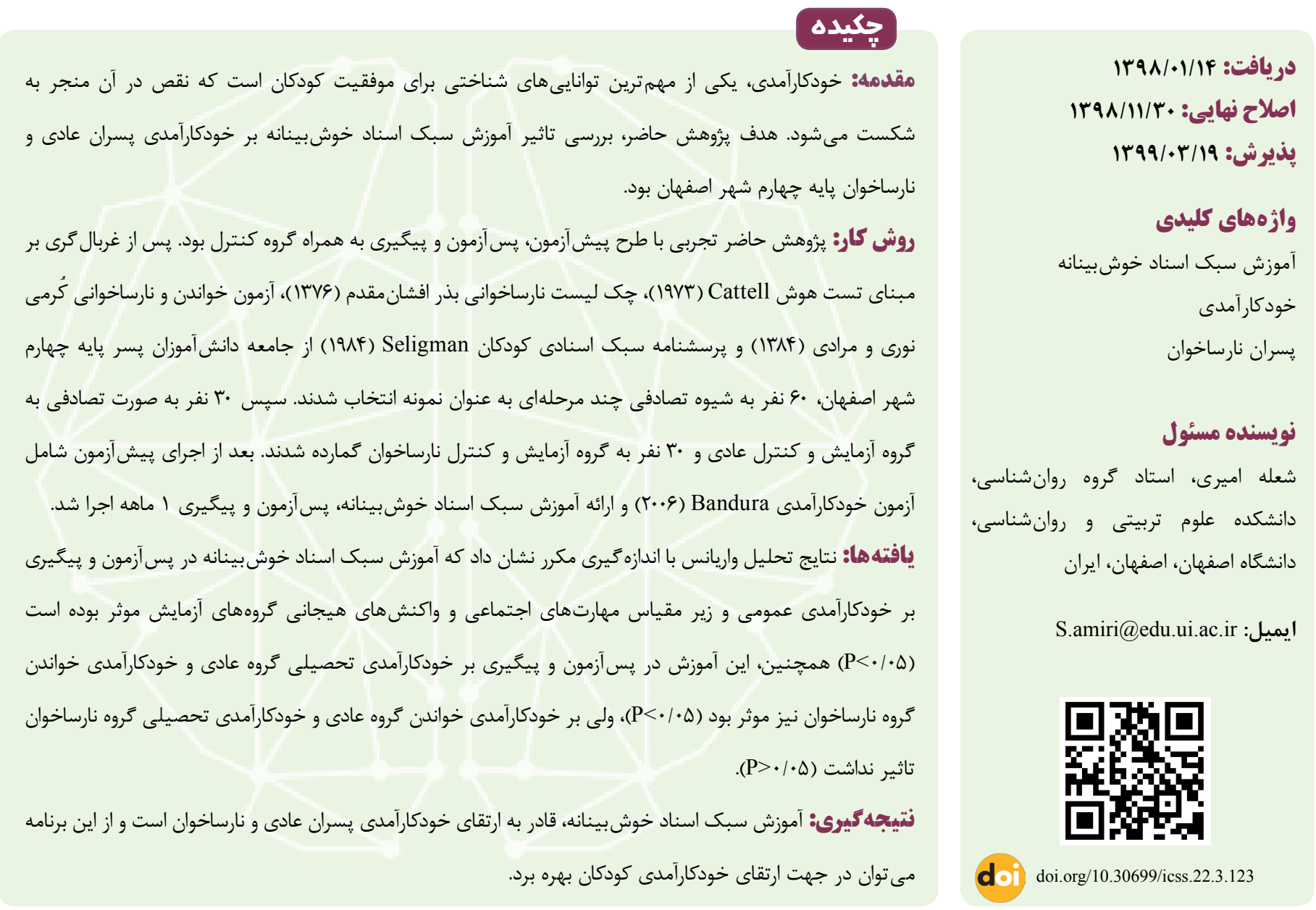

مقدمبه

اعمال است؛ به گَونهاى كه زندگى انسانها توسط خودكارآمدى آنها

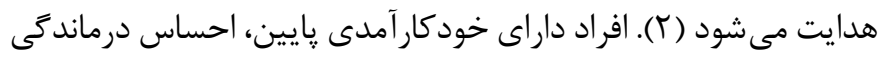
مى كنند و اعتقاد دارند، تلاش هايشان، بى فايده است. در مقابل، افراد داراى خود كارآمدى بالا، باور دارند كه مىتوانند به شيوه موثرى با وقايع مواجه شوند؛ به همين خاطر در كارها از خود استقامت نشان مىدهند
خودكارآمدى يكى از مهممترين توانايى هاى شناختى در زندگى است و از نظر Bandura (919 () به باور افراد درباره توانايى انجام موفق وظايف در موقعيتهاى خاص اشاره دارد كه روى مواردى مثل انتخاب تكاليف، تلاش و يشتكار فردى در رويارويى با جالش ها و همجنين روى يادَيرى

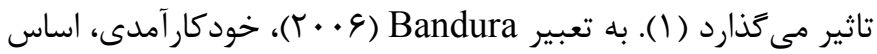


مخدوش كودكان نارساخوان بايد مورد توجه و هدف برنامه مداخلهاى قرار گيرد تا عملكرد آنها نيز بهبود يابد. يكى از روش هاى موثر ارتقاى سطح خودكار آمدى، آموزش سبك اسناد خوشبينانه است؛ خوشبينى، از نظر Seligman يك سبك اسناد ساختاريافته است كه منشا آن، شيوه تفكر افراد درباره علتها است. هر فردى در انتساب امور به علل مختلف، عادتهاى ويزهاى دارد كه سبك اسناد ناميده مىشود. سبك اسناد در كودكى شكل مى در صورتى كه از بيرون، دخالتى در آن صورت نخيرد، در تمام عمر ثابت باقى مىماند. كودكان در تبيين اين كه جرا رويدادهاى خوب يا بد براى آنها رخ مى دهد، از سه بعد استفاده مى كنند كه شامل تداوم، فراگير بودن و شخصى سازى است. اخر كود كان، درباره شكست هاى خود، كلمه هميشه را به كار مىبرند، سبك اسناد بدبينانه دارند و اگر در اين موارد از كلمه بعضى وقتها استفاده مى كنند، پييرو سبكى خوش بينانه هستند. كودكان بدبين در مورد شكستهاى خود، به تعميمهاى كلى دست مىزنند ولى كودكان خوشبين در مورد شكست هايشان به تبيينهاى اختصاصى مىيردازند. كودكان بدبين، همجنين خود را به صورت فراخير و دائمى نكوهش مى كنند ولى كودكان خوشبين خودشان را به شكل موقت و اختصاصى نكوهش مىنمايند (r I). از نظر Bandura (ع • • r) افرادى كه باورهاى خودكار آمدى بالايى دارند، هدف هاى جالشبرانگيزى براى خودشان در نظر مى گيرند و انتظار دارند كه تلاشهايشان، نتايج مثبت به بار آورد. جنين افرادى به جاى له

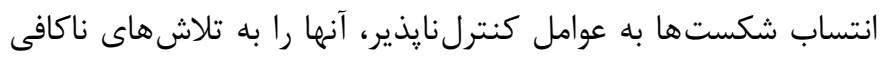

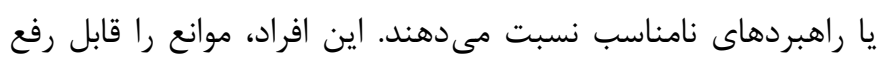
و مسائل را قابل حل در نظر مى گيرند و در جهت دستيابى به اهداف خود، با پشتكار تلاش مى كنند (r). بنابراين، يكى از راههاى ارتقاى رئ خودكارآمدى، افزايش افكار خوشبينانه است و يزوهش هاى متعددى

بر ارتباط خوشبينى و خود كارآمدى صحه كذاشتهاند (9 - با ). به طور كلى مى توان كفت كودكان در طول زندگى با مشكلاتى رو به رو مىشوند كه بر روى خوشبينى آنها تاثير منفى كذاشته و موجب بدبينى آنها مىشود؛ در اين ميان، كودكان نارساخوان، به دليل نقصها و مشكلات متعددى كه همواره در عرصههاى مختلف زندگيشان تجربه مى كنند، به گونهاى خاصتر، اسير بدبينى مىشوند و اين حالت، تاثيرات منفى بر خودكارآمدى آنها بر جاى مى گذارد. در اين ميان، يروتكل آموزش سبك اسناد خوشبينانه Seligman، مطابق با نتايج يزوهشهاى متعدد، با ارائه آموزش هاى متنوع موثر بر خودكارآمدى،

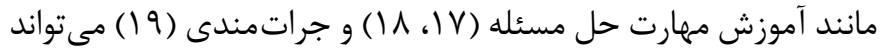
به عنوان مداخلهاى موثر به اين وضعيت پايان دهد و كودكان را از بدبينى
و غالبا در سطح بالا عمل مى كنند. خود كارآمدى بالا، ترس از شكست را كم مى كند، سطح اهداف را ارتقا مىدهد و توانايى حل مسئله را تقويت مى كند. خود كارآمدى بالا، همجنين بر سطح انخيزش فرد تاثير مى كذارد و ميزان تلاش و يشتكار را تقويت مى كند (؟ّ).

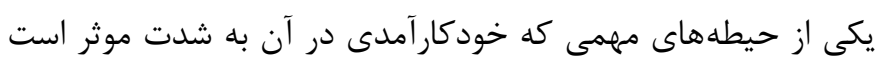
يادگيرى مىباشد. يادگيرى يكى از مهمترين حيطهها در زندكى افراد

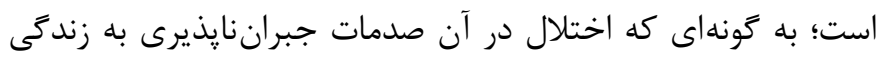
وارد مى سازد و مداخله سريع در آن ضرورت مى يابد. اختلال در فر آيند يادگيرى، مى تواند به صور مختلف رخ دهد؛ يكى از انواع اختلالات

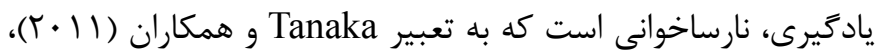
يك اختلال عصبشناختى است كه در آن فرد علىرغم داشتن هوش كآن طبيعى و فرصتهاى آموزشى كافى در كسب مهارتهاى خواندن با مشكل مواجه مى گردد (Y). كود كان مبتلا به نارساخوانى، معمولا وازهها

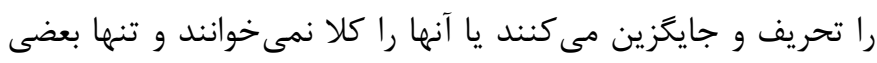
از مطالب خوانده شده را درك مى كنند (ه). به دليل اين كه توانايى خواندن، زيربناى اكتساب علم و دانش است، اين توانايى به عنوان يكى از ضرورى ترين قابليت هاى بشرى شناخته مى شود كه توجه همه جانبه به ابعاد مختلف آن بسيار اهميت دارد (ع). در باب اهميت نارساخوانى، بايد گفت كه طبق نتايج يزوهشها، حدورا • مدرصد كود كان مبتلا به اختلالات يادگيرى در اين دسته قرار مى گيرند كه شيوع آن در يسرها سه تا جهار برابر بيش از دخترها است (V). دانش آموزان مبتلا به اختلالات يادگيرى از جمله دانش آموزان نارساخوان، افزون بر مشكلات تحصيلى، در برخى زمينهاى مههم روانشناختى هم دجار مشكل هستند. براى مثال، خود كارآمدى آنها، اغلب دجار دهار اختلال مى شود ( • 1-1). از آنجايى كه عملكرد موفق فرد، نقش مهمى در ارتقاو حفظ خود كار آمدى دارد (T) و در اين كودكان به دليل ضعف تحصيلى، نه تنها موفقيت هاى جشمخير ديده نمى شود، بلكه شكست هاى مكرر توسط

آنها تجربه مىشود، خودكار آمدى به شدت صدمه مىبيند. با توجه به تاثيرات مثبت خود كارآمدى بر عملكرد و زيان ناشى از نقص آن مخصوصا در كودكى، بايد در جهت ارتقاى سطح خود كارآمدى افراد كام برداشت و بر اساس اين كه كودكان نارساخوان خود كار آمدى يايينى

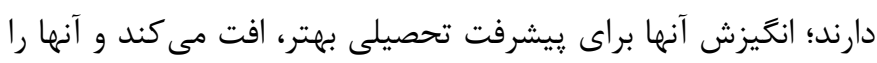
در يك موقعيت راكد نكه مى دارد. در يك سيكل باطل، خودكار آمدى مختل شده بر توانايى هاى يادكيرى افراد نارساخوان تاثير منفى كذاشته

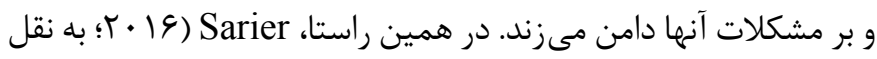
از Yuksel و همكاران)، در يزوهشى نشان داد كه مهممترين عامل موثر در موفقيت تحصيلى، خودكار آمدى است (1 (1). بنابراين خود كارآمدى 
در مصاحبه اوليه يزوهشكر با وى، داشتن بهره هوشى نرمال بر اساس آزمون هوشى، داشتن سبك اسناد بدبينانه بر اساس ابزار شناسايى

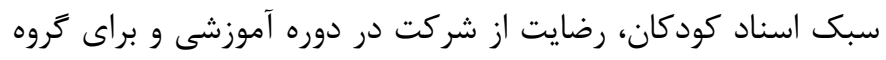

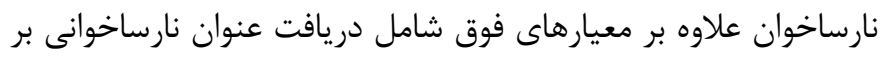

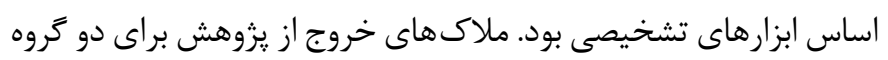

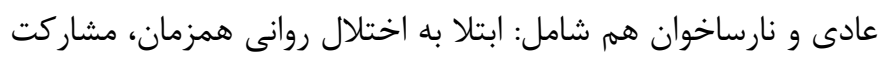
همزمان در برنامه هاى آموزشى_درمانى ديخر، عدم علاقهمندى به ادامه شركت در جلسات و غيبت بيش از Y جلسه بود.

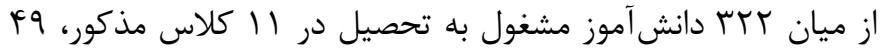
نفر مشكوك به نارساخوانى بودند كه از طريق يك مصاحبه اوليه با معلمين انتخاب شده بودند (ويزگى هاى دانشآموزان نارساخوان بر

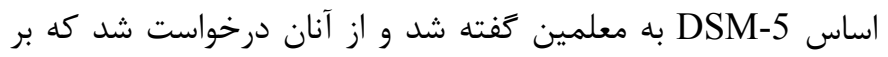

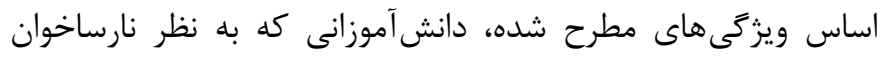

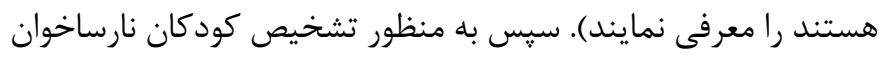

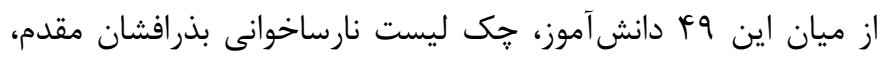

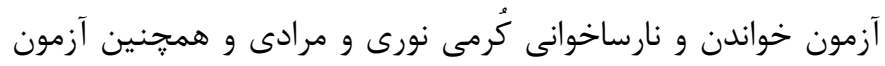
هوشى Cattell، استفاده شد. براى انتخاب دانشآموزان نارساخوان، كسانى كه بر اساس קك ليست نارساخوانى بذرافشان مقدم، نارساخوان

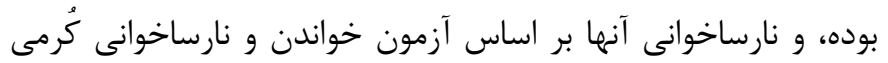

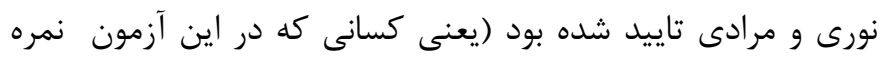

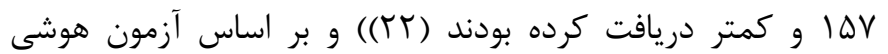
Cattell

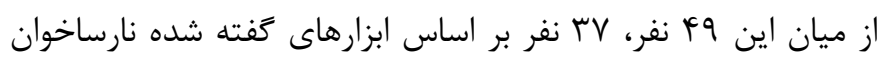

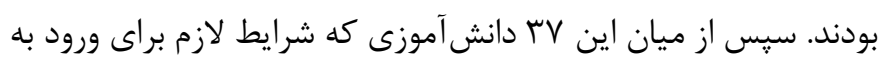

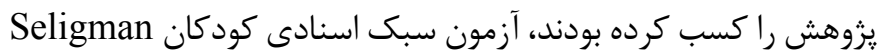

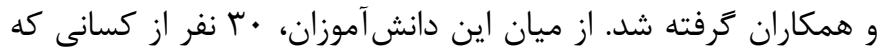
سبك اسنادى بدبينانه داشتند، براى ورود به يزوهش انتخاب شدند.

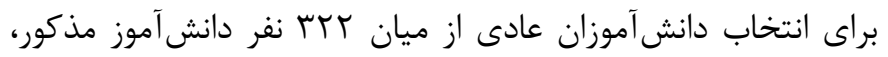

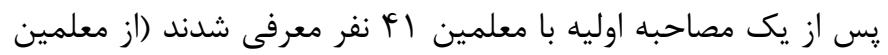

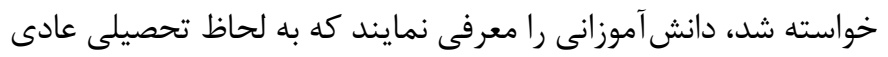

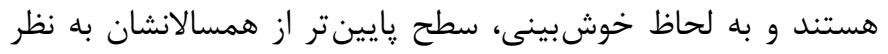

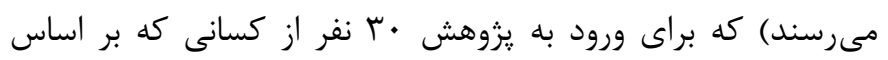

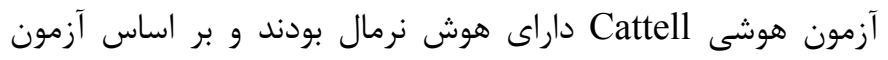
سبك اسنادى كودكان Seligman و همكاران، سبك اسناد بدبينانه داشتند، انتخاب شدند و از بين دو گروه نارساخوان و عادى كه شرايط لازم براى شركت در يزوهش را به دست آورده بودند، به صورت تصادفى نانى ها نفر به هر گروه، گمارده شدند. البته حجم نهايى نمونه يس از
به سمت خلق بالاتر (·r)، شناخت و توجه بهتر (Y)) و خوشبينى،

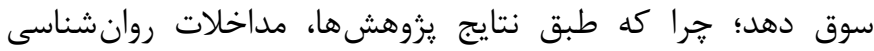
مثبت، مى تواند مكمل ديگر روشها، در ارتباط با ِيشگيرى و درمان

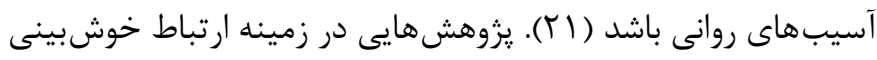

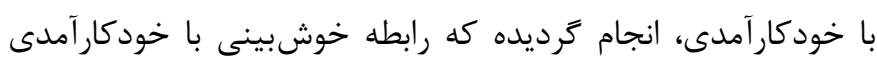

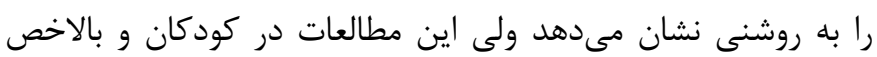
كودكان نارساخوان جه در ايران و جه در خارج از ايران كمتر انجام شده

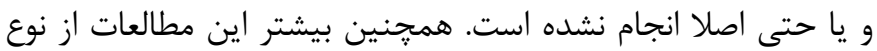
همبستكى بوده و تاثير خوشبينى بر خودكارآمدى را به صورت يك مداخله مجزا مورد بررسى قرار نداده است؛ بنابراين، با توجه به مطالب مذكور، اين يزوهش با هدف بررسى اثربخشى آموزش سبك اسناد

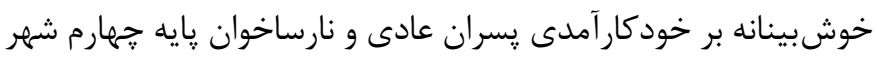

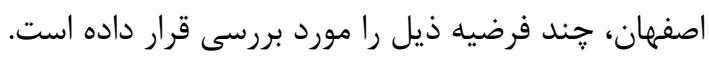

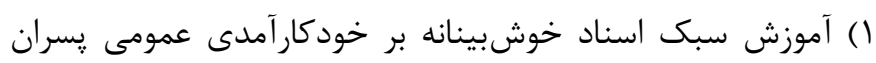

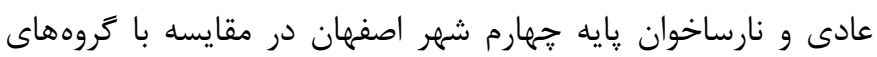
كنترل در يس آزمون و يِيخيرى موثر است. r) آموزش سبك اسناد خوشبينانه بر خودكارآمدى تحصيلى و وآن خودكار آمدى خواندن يسران عادى و نارساخوان بايه جهارم شهر اصفهان

در مقايسه با گروههاى كنترل در يس آزمون و پِيخيرى موثر است. r) آموزش سبك اسناد خوشبينانه بر مهارتهاى اجتماعى و و

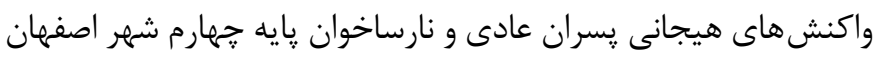
در مقايسه با گروههاى كنترل در يس آزمون و يِيخيرى موثر است.

\section{روش كار}

طرح يزوهش حاضر، از نوع تجربى با پِيشآزمون، يِ آزمون، پِيَيرى

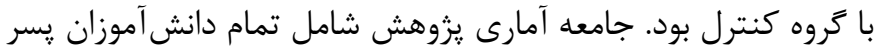

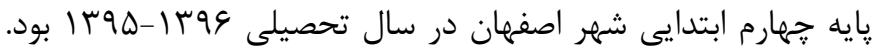
روش نمونه گيرى، تصادفى جند مرحلهاى بود؛ بدين منظور، به انتخاب

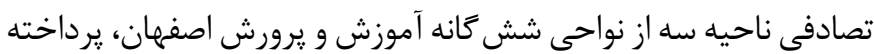
شد؛ سيس از بين مدارس يسرانه دوره ابتدايى اين ناحيه، ينج مدرسه به

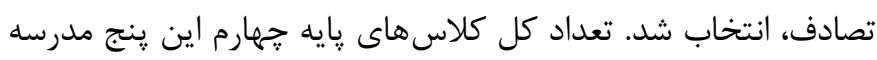

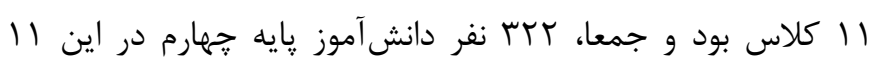

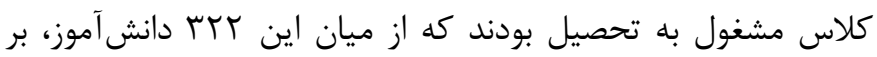

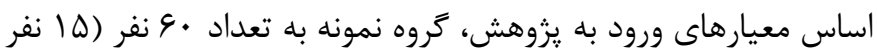
كروه آزمايش عادى، ها نفر كروه كنترل عادى، ها نفر گروه آزمايش نارساخوان، ها نفر گروه كنترل نارساخوان) انتخاب شدند. اين معيارها براى كروه عادى شامل: داشتن سن • (-9 سال، معرفى توسط معلم 


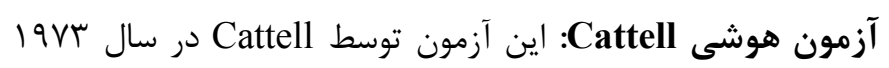

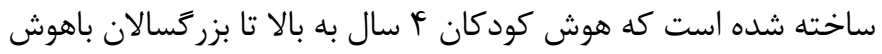

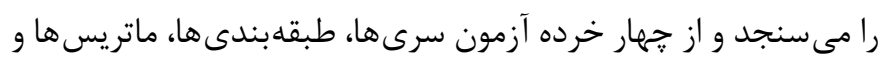

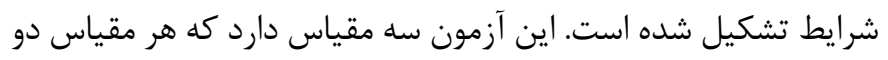

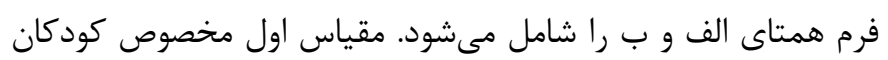

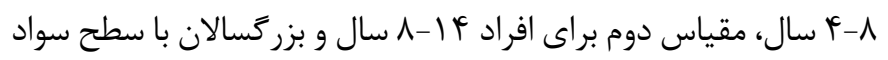

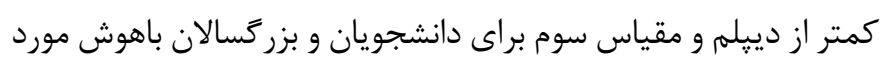

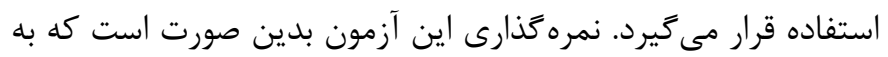

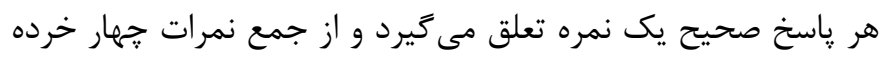

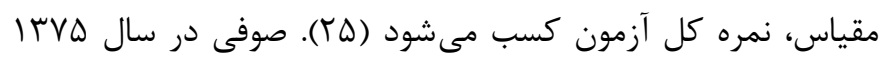

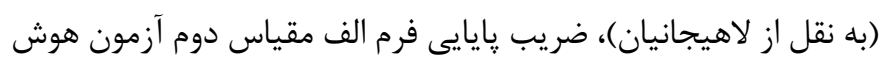

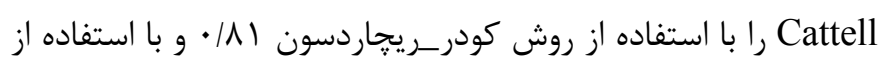

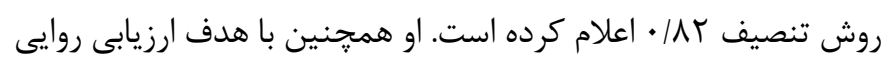

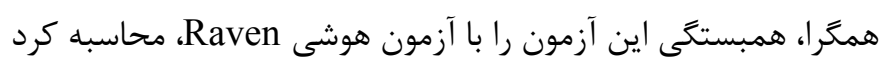

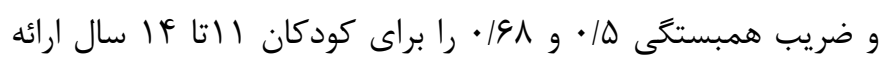

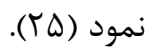

\section{يرسشنامه سبك اسنادى كودكان (Style Questionnaire}

\section{Seligman Children Attributional}

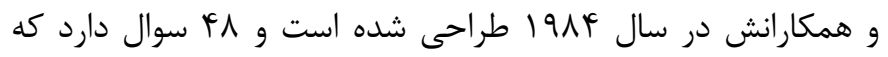

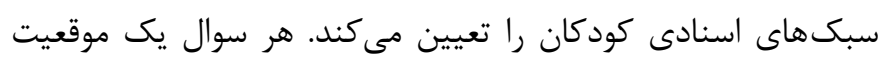

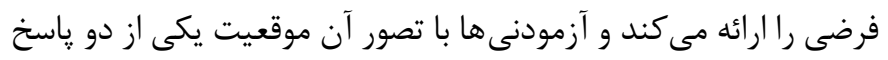

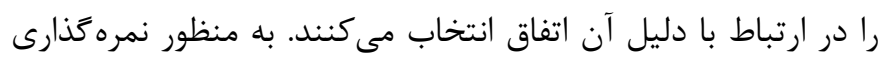

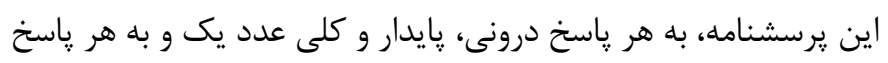

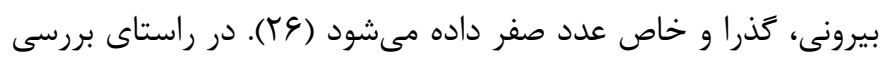

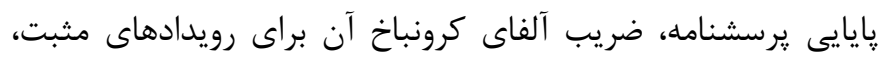

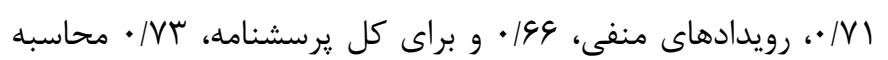

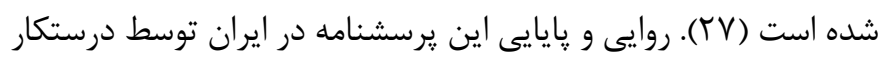

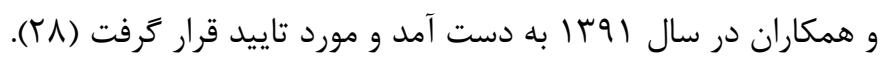

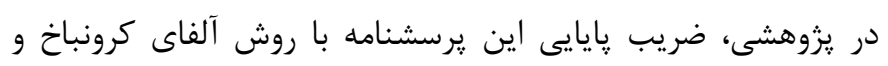

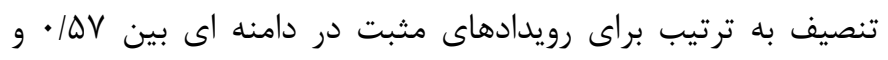

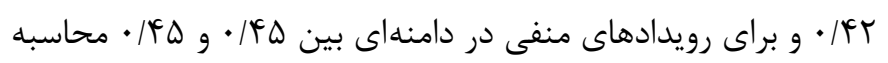

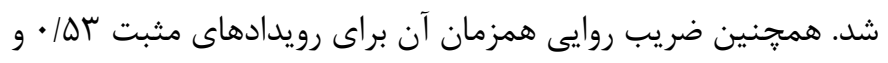

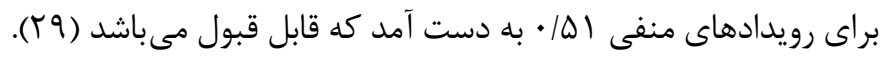

يرسشنامه خودكار آمدى: اين يرسشنامه بر اساس نظريه Bandura،

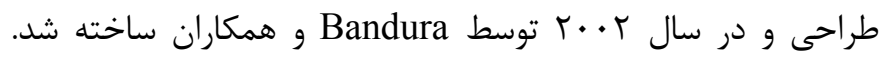

ريزش ^ نفر، به كله نفر رسيد؛ به طورى كه در هر تروه، سا نفر حضور

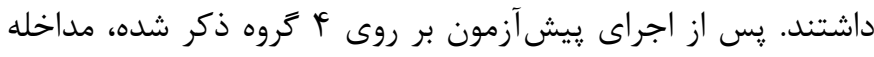

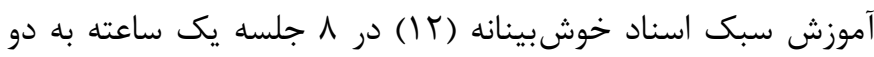

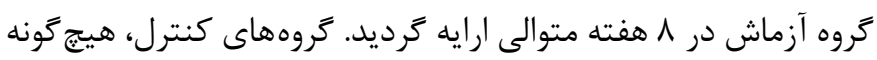

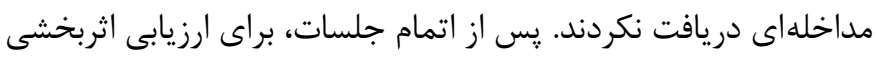

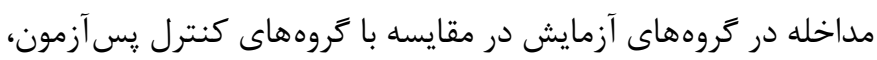

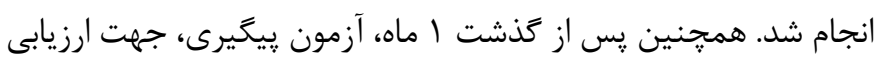

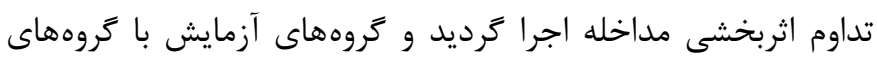

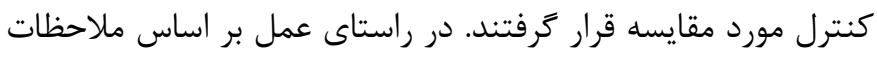

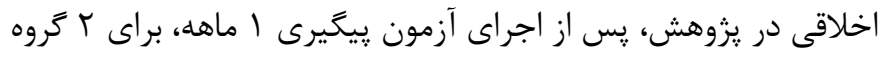

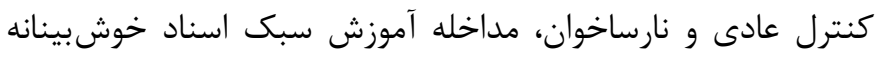
به صورت فشرده اجرا گرديد. از ابزارهاى زير براى جمعآ آورى دادهـها استفاده شد: - اسو

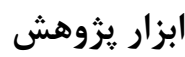
جك ليست نارساخوانى بذر افشان مقدم: اين جى ليست، وسيلهاى

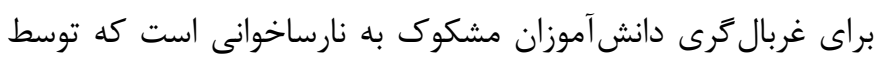
بذرافشان مقدم در سال ITV

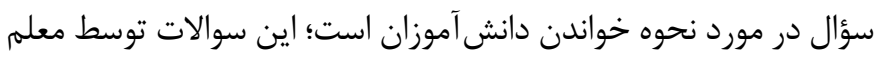

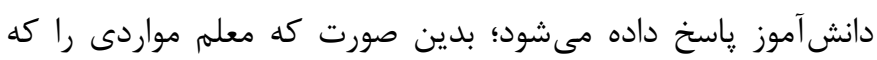
به صورت مكرر در عملكرد دانش آموزش ديده است، انتخاب مى دنمايد.

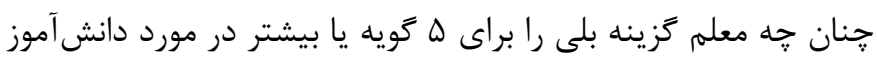

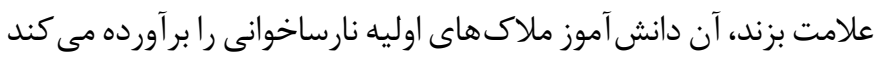

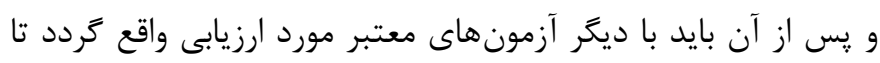

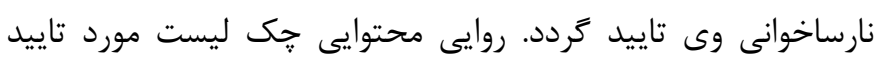

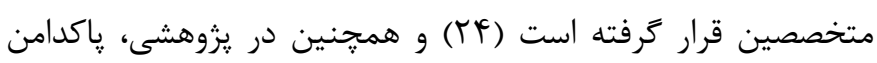

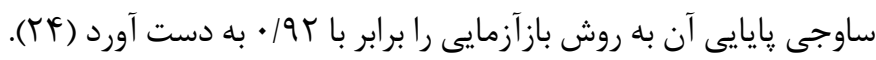

آزمون خواندن و نارساخوانى كُرمى نورى و مرادى: اين آزمون

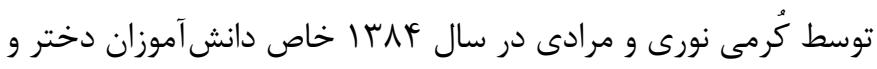

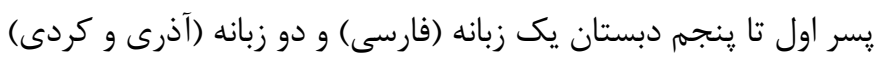

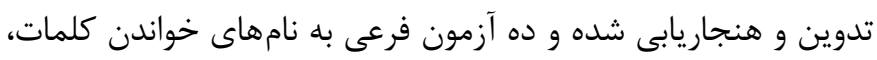

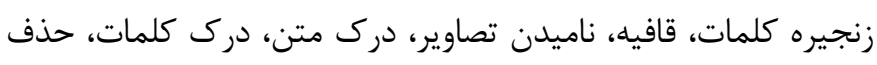

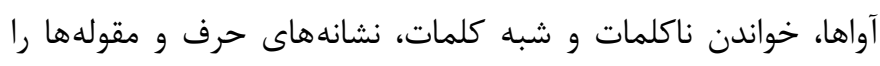

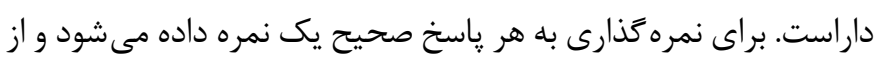

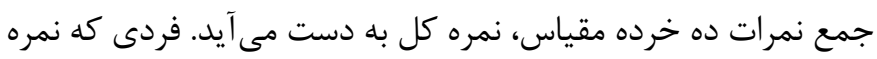

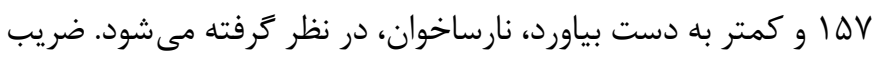

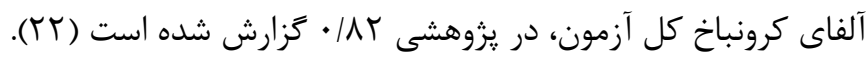


تا خيلى خوب مىتوانم، تنظيم مىشود كه بر اساس طيف ليكرت از ا تا F درجهبندى مىشود. روايى محتوايى اين آزمون توسط ه استاد متخصص دانشعاه اصفهان، بررسى و تاييد شده است. در يزوهشى،

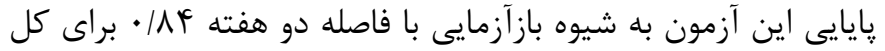

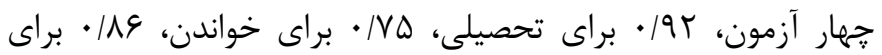
مهارتهاى اجتماعى و AF| • براى واكنش هاى هيجانى به دست آمد

\section{برنامه آموزش سبك اسناد خوش بينانه: اين برنامه توسط} طeligman گروههاى عادى و نارساخوان آزمايش ارائه گرديد. در جدول ال، خلاصهاى از محتواى آموزشى ارائه شده است.
سيس در سال و + •r، توسط Mercer مورد بازبينى قرار گرفت. ضريب

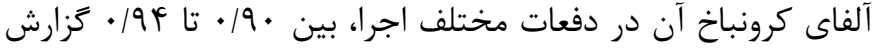
شده است. اين يرسشنامه شامل • • سوال است و خود كار آمدى تحصيلى (• سوال اول)، خودكارآمدى خواندن (• (1 سوال دوم)، مهارتهاى اجتماعى (·• سوال سوم) و واكنش هاى هيجانى (· • سوال جهارم) را در بر مى گيرد. حوزه تحصيلى، تمركز حواس در كلاس، علاقه به درس، رويارويى با امتحان و انتظارات والدين را شامل مىشود. حوزه خواندن، شامل توانايى خواندن و فهم مطالب خوانده شده است. حوزه هيجانى، شناخت و تنظيم عواطف خود و ديگران را در بر مى اجتماعى، دوست يابى، دانش اجتماعى و كاربرد مهارتهاى اجتماعى را شامل مىشود. نمره خودكارآمدى عمومى، نيز به جمع نمرات يرسشنامه اشاره دارد. دامنه پِاسخ به صورت جهار ززينه اصلاً نمى توانم

جدول ا. خلاصه محتواى جلسات آموزش سبك اسناد خوشبينانه

\begin{tabular}{|c|c|}
\hline محتواى آموزشى & جلسه \\
\hline معارفه، آموزش مفاهيم فكر، احساس و رفتار به عنوان پيش زمينه آشنايى با مدل شناختى ABC & اول \\
\hline آموزش مدل شناختى ABC از طريق تمرين با تصاوير كارتونى و نمونههاى شفاهى & دوم \\
\hline آموزش سبك اسناد خوشبينانه و بدبينانه & سوم \\
\hline آموزش ابعاد سه كانه سبك اسناد شامل تداوم، شخصى سازى و فراكير بودن & جهارم \\
\hline آموزش مدل شناختى ABCDE و نحوه مجادله موثر با نخرشهاى فاجعهآميز & ينجم \\
\hline آموزش مجادله سريع، كاربرد مدل شناختى ABCDE و آموزش اجتناب از فاجعه يندارى & ششم \\
\hline 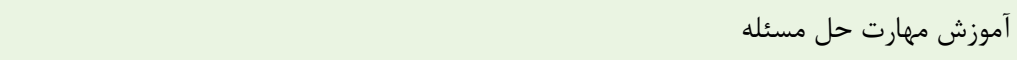 & هفته \\
\hline آموزش مهارت جرات مندى & هشتم \\
\hline
\end{tabular}

خودكار آمدى و مؤلفه هاى آن (به جز خودكار آمدى خواندن) در گروه آزمايش، ميانگين نمرههاى يسآزمون و پيخيرى نسبت به پيشآزمون تغيير يافته، اما در گروه كنترل در هر سه بار آزمون تفاوت به اندازه گروه آزمايش محسوس نيست. همجنين در گروه نارساخوان در خود كارآمدى و مؤلفههاى آن (به جز خودكارآمدى تحصيلى) در زروه آزمايش، ميانگين نمرههاى يسآزمون و رييخيرى نسبت به پيشآزمون تغيير

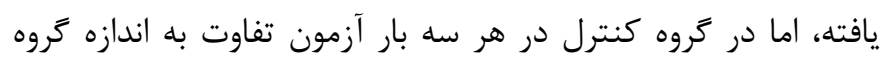
آزمايش محسوس نيست. قبل از استفاده از آزمون تحليل واريانس با اندازهگيرى مكرر ييشفرضهاى مربوط به اين آزمون مورد بررسى قرار گرفتند. براى بررسى وضعيت نرماليتى دادههاى متغير خود كارآمدى و مؤلفههاى آن

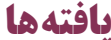

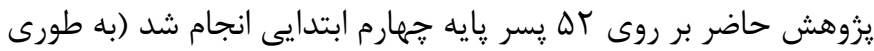
كه قبلا اشاره شد تعداد نمونه يس از ريزش به ها هن نفر كاهش يافت) كه צr نفر از آنها عادى و צr نفر ديگر نارساخوان بودند. جهت بررسى فرضيه هاى يزوهش، با مدنظر قرار دادن ييشفرض هاى مربوطه از آزمون تحليل واريانس با اندازهزيرى مكرر استفاده گرديد كه نتايج در ادامه كزارش شده است. ابتدا شاخصهاى توصيفى مانند ميانگين، انحراف استاندارد و تعداد آزمودنى هاى نمونه مربوط به نمرات يِيشآزمون،

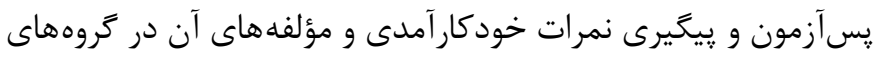
آزمايش و كنترل در جدول r گزارش شده است. مقادير برآورد شده در جدول ץ بيان گر اين است كه در زروه عادى در 
استفاده گرديد كه مقادير مربوط به آن نشاندهنده برقرارى يِيش فرض

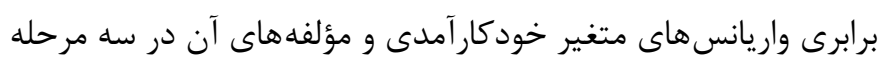

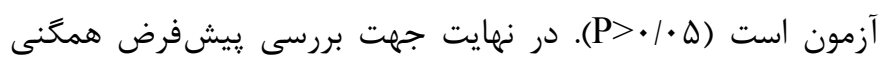

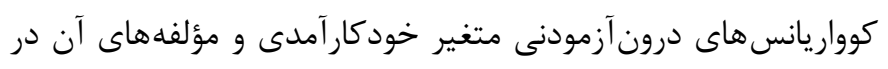

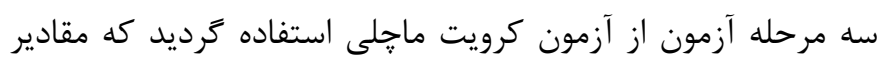

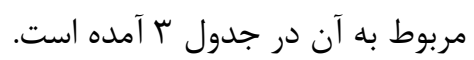

در بين گروههاى آزمايش و كنترل از آزمون شإِيرو-ويلك استفاده

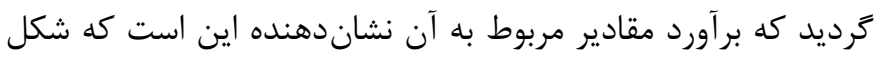

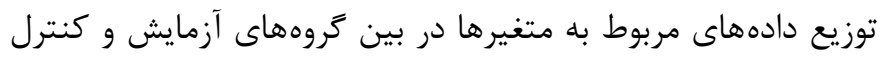

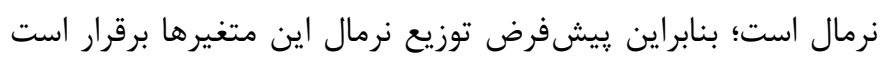

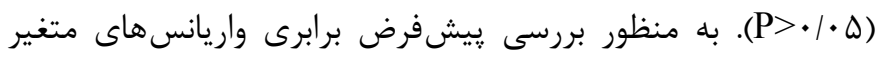

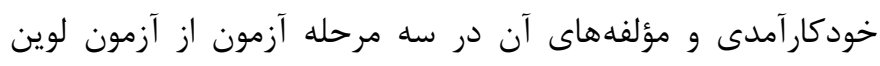

جدول r. ميانكَين و انحراف معيار نمرات بيشآزمون، يسآزمون و يِيَيرى خودكارآمدى و مؤلفههاى آن در كروههاى مورد مطالعه

\begin{tabular}{|c|c|c|c|c|c|c|c|c|c|}
\hline \multicolumn{2}{|c|}{ ييخيرى } & \multicolumn{2}{|c|}{ يس آزمون } & \multicolumn{2}{|c|}{ ييش آزمون } & \multirow{2}{*}{ تعداد } & \multirow{2}{*}{ كروه } & \multirow{2}{*}{ متغير } & \multirow{2}{*}{ كروه } \\
\hline انحراف معيار & ميانغين & انحراف معيار & ميانگين & انحراف معيار & ميانكين & & & & \\
\hline$q / D F F$ & IF./GTY & $N / r I I$ & IFT/YAT & $1.1 . \mathrm{r}$. & ITF/QTY & ir & آزمايش & \multirow{2}{*}{ خودمار آمدى } & \multirow{10}{*}{ عادى } \\
\hline V/GTY & ITVIGYT & N/TF. & ITV/GTY & $9 / 111$ & r & ir & كنترل & & \\
\hline$F / Y M A$ & $r F / r \wedge F$ & r/VAr & $r \Delta / / \Delta r$ & $F / 9 . q$ & $r|/ \& \varepsilon|$ & זו & آزمايش & \multirow{2}{*}{ خودكار آمدى } & \\
\hline$r / \mu \cdot r$ & & r/AVI & $r q / \cdot V q$ & $r / F \mid Q$ & $r q / \ldots$ & ir & كنترل & & \\
\hline T/FrG & 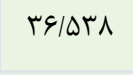 & $r / 4 \& V$ & rg/rAf & T/VAV & $r F / 4 q\rangle$ & ir & آزمايش & \multirow{2}{*}{ خودكار آمدى خون } & \\
\hline $1 / v 91$ & MF/Fql & r/TaY & $r \Delta / \cdot \vee \varphi$ & $1 / 9 \Delta T$ & rF/gqT & ir & كنترل & & \\
\hline$r / 911$ & rF/VGq & T/MTK & $r \Delta / r \cdot \gamma$ & T/IVQ & $r \cdot / r \cdot v$ & r & آزمايش & \multirow{2}{*}{ اجتمارت هاىى } & \\
\hline$r / T \Delta \cdot$ & $r \cdot 199 r$ & $r / 911$ & $r \cdot / \wedge+\varepsilon$ & r/Arq & $r \cdot / 9 r r$ & ir & كنترل & & \\
\hline $1 / 191$ & TY/QTr & $r / T \Delta \Lambda$ & $r \Delta / \Delta r \Lambda$ & T/VVT & TNIGAT & ir & آزمايش & \multirow{2}{*}{ واكنش هاى } & \\
\hline r/FAF & TN/AFS & $r / r \cdot r$ & TV/aTr & r/grq & $r 9 / \Delta \Gamma \wedge$ & r & كنترل & & \\
\hline $1 \cdot / \Lambda r \Lambda$ & $\| V / / \Delta T$ & $11 / 4 q 4$ & IIN/DFT & $N|F|$. & $q q / \cdot r V$ & r & آزمايش & \multirow{2}{*}{ خودمار آمدى } & \multirow{10}{*}{ نارساخوان } \\
\hline F/FTV & $q F / \Delta r \Lambda$ & $9 / 09$. & 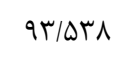 & $9 / 991$ & $9 F / A+\varepsilon$ & r & كنترل & & \\
\hline$F / N Q T$ & $r q / \cdot V q$ & F/Mrq & $r q 1 \ldots$ & $r / 099$ & Tr/rAF & ir & آزمايش & \multirow{2}{*}{ خودكار آمدى تحصيلى } & \\
\hline $1 / 191$ & $r r / 491$ & T/VQF & $r \pi / r \Lambda$ & $1 / 941$ & $r r / \cdots$ & ir & كنترل & & \\
\hline$F / \Delta Q F$ & TE/9Tr & F/GTG & $r \varepsilon / \ldots$ & $r / \cdot 14$ & rr/rAk & ir & آزمايش & \multirow{2}{*}{ خودكار آمدى } & \\
\hline$r / \cdot 10$ & $r T / r \cdot V$ & $r / \cdot \Lambda V$ & rT/Tr. & I/ArT & $r r / v 9 q$ & ir & كنترل & & \\
\hline$r / \mu \cdot \varphi$ & rI/ArA & T/YIT & rr/GqT & r/9/4 & $r \Delta / \ldots$ & ir & آزمايش & \multirow{2}{*}{ اجتمارتى هاى } & \\
\hline$r / \cdot v r$ & $r F / g \mid d$ & S & $r F / q q T$ & T/VAT & $r F / \cdot V q$ & ir & كنترل & & \\
\hline T/VYF & $r Y / G / Q$ & $r / 9 \cdot 9$ & rr/Afs & $r / T \cdot \varphi$ & rr/DrA & ir & آزمايش & \multirow{2}{*}{ واكنش هاى } & \\
\hline r/MAF & $r F / l \Delta r$ & $r / F A M$ & $r r / r r$. & $r / q .$. & $r F / \ldots$ & ir & كنترل & & \\
\hline
\end{tabular}


جدول r. برآورد مقادير آزمون ماجلى جهت بررسى همكنى كوواريانسهاى درونآزمودنى متغير خودكار آمدى و مؤلفهاى آن در كروههاى مورد مطالعه

\begin{tabular}{|c|c|c|c|c|c|}
\hline درجه آزادى & $\mathbf{P}$ & كاى اسكوئر & آماره ماجلى & متغير & تروه \\
\hline r & $\cdot / 191$ & $r / \Delta 99$ & $\cdot / 1 \Delta \Delta$ & خودكار آمدى عمومى & \multirow{5}{*}{ 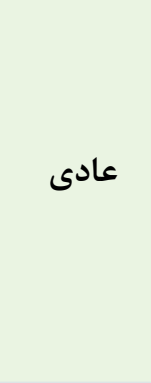 } \\
\hline r & - IATF & $\cdot / r \wedge V$ &.$/ 94 r$ & خودكار آمدى تحصيلى & \\
\hline r & $\cdot 1091$ & $1 / 4 V$ & $\cdot / 909$ & خودكار آمدى خواندن & \\
\hline r & $\cdot 1941$ & $\cdot 19 \cdot$ & .1995 & مهارت هاى اجتماعى & \\
\hline r & $\cdot \pi l i$ & . NRT &.$/ 9 V V$ & واكنش هاى هيجانى & \\
\hline r &.$/ 1 T V$ & $1 / 91$. & $\cdot / 9 \cdot 1$ & خود كار آمدى عمومى & \multirow{5}{*}{ نارساخوان } \\
\hline r &.$/ 199$ & $r / \Delta 9)$ & $\cdot / \wedge \Delta \Delta$ & خودكار آمدى تحصيلى & \\
\hline r &.$/ 114$ & 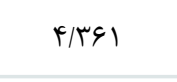 & $\cdot / A T Y$ & خودكار آمدى خواندن & \\
\hline r & $\cdot /|r|$ & F/TMT & - /Nrt & مهارت هاى اجتماعى & \\
\hline r & . /NTA & . $/ \Delta F$ & $.19 \Delta 4$ & واكنش هاى هيجانى & \\
\hline
\end{tabular}

تحليل واريانس با اندازه خيرى مكرر يكى از برون دادها، تحليل

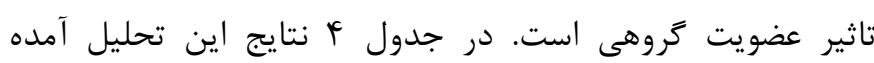

مقادير مربوط به جدول "َ، بيانگر اين است كه پيشفرض همخنى

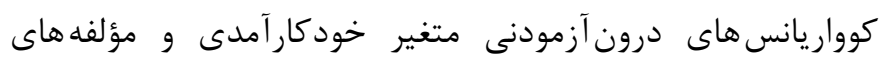

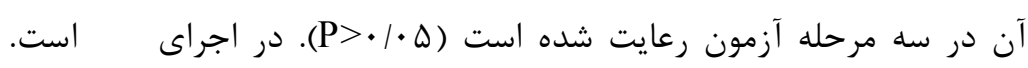

جدول F. برآورد مقادير تحليل واريانس با اندازهيرى مكرر براى اثرات اصلى و تعاملى در كروههاى مورد مطالعه

\begin{tabular}{|c|c|c|c|c|c|c|c|c|}
\hline ميزان تأثير & $\mathbf{P}$ & درجه آزادى & $\mathbf{F}$ & ارزش & آزمون & روش & متغير & كروه \\
\hline$\cdot|A| \Delta$ & $\cdot / \ldots$ & $r$ & $\Delta \cdot / v \cdot \Lambda$ & $\cdot / \wedge \Delta$ & لامبداى ويلكز & زمان & \multirow{2}{*}{ خودمار آمدى } & \multirow{10}{*}{ عادى } \\
\hline - INGT &.$/ \cdots$ & $r$ & VI/qVF & .//rی & لامبداى ويلكز & زمان*كروه & & \\
\hline$\cdot / r q$. & $\cdot \cdot \cdot r$ & $r$ & V/rrA &.$|9|$ & لامبداى ويلكز & زمان & \multirow{2}{*}{ خودكار آمدى تحصيلى } & \\
\hline.$/ r q 4$ & r... & $r$ & V/FAV & .19 .4 & لامبداى ويلكز & زمان*كروه & & \\
\hline$.|| f \mid$ & $.1 . \Delta F$ & r & r/g4A & $\cdot / v \Delta Q$ & لامبداى ويلكز & زمان & \multirow{2}{*}{ خودكار آمدى } & \\
\hline . / FF & $\cdot / \cdot \Delta T$ & $r$ & r/VIr & $\cdot / V \Delta S$ & لامبداى ويلكز & زمان*كروه & & \\
\hline$\cdot / \Delta \Delta$ & $\cdot / \ldots$ & $r$ & $|F| \cdot F A$ & $\cdot / 4 \Delta$ & لامبداى ويلكز & زمان & \multirow{2}{*}{ مهارتهاعى اجتى } & \\
\hline$\cdot \mid \Delta \Lambda$ & $\cdot 1 \ldots$ & $r$ & $\mid Q / \wedge \varphi$ & . KF. & لامبداى ويلكز & زمان*كروه & & \\
\hline.$/ 490$ & $\cdot 1 \ldots$ & $r$ & $\mid 1 / r 91$ & $\cdot 10 \cdot 0$ & لامبداى ويلكز & زمان & \multirow{2}{*}{ واكنش هاى } & \\
\hline . & $.1 \cdots$ & r & $r .1 .99$ & . MGG & لامبداى ويلكز & زمان*كروه & & \\
\hline
\end{tabular}




\begin{tabular}{|c|c|c|c|c|c|c|c|c|}
\hline ميزان تأثير & $\mathbf{P}$ & درجه آزادى & $\mathbf{F}$ & ارزش & آزمون & روش & متغير & كروه \\
\hline$\cdot / V \Delta \Delta$ & $\cdot 1 \ldots$ & r & ra/RTr & $\cdot \pi F \Delta$ & لامبداى ويلكز & زمان & \multirow{2}{*}{ خود كار آمدى } & \multirow{10}{*}{ نارساخوان } \\
\hline ./vq1 & $\cdot \ldots$ & r & FT/DG. & $\cdot / \pi \cdot 9$ & لامبداى ويلكز & زمان*تروه & & \\
\hline $.11 \cdot 1$ & $\cdot / \cdot \Delta r$ & r & $r / .9 V$ & $\cdot / N \Delta \Delta$ & لامبداى ويلكز & زمان & \multirow{2}{*}{ خودكار آمدى تحصيلى } & \\
\hline .1 .91 & $.1 .9 V$ & r & $1 / \cdot 1$ &.$/ 9 T F$ & لامبداى ويلكز & زمان*كروه & & \\
\hline . & $\cdot / \ldots$ & r & II/AAV & $\cdot / V 19$ & لامبداى ويلكز & زمان & \multirow{2}{*}{ خود خار آمدى } & \\
\hline . & ${ }^{\prime} \cdot r r$ & r & N/VII & $\cdot 1099$ & لامبداى ويلكز & زمان*كروه & & \\
\hline . MIT & $\cdot 1 \cdots$ & r & гN/rq. & $\cdot / T A \Lambda$ & لامبداى ويلكز & زمان & \multirow{2}{*}{ اجتمارتى هاى } & \\
\hline . IGAT & $\cdot \ldots$ & r & $r \cdot 19 \cdot 9$ & $\cdot \pi \Delta \Lambda$ & لامبداى ويلكز & زمان*تروه & & \\
\hline $.19 \Delta F$ & $\cdot \cdots$ & $r$ & $r I / V \Delta \Lambda$ & 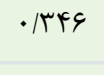 & لامبداى ويلكز & زمان & \multirow{2}{*}{ واكنش هاى } & \\
\hline $.19 \wedge F$ & $\cdot \cdots$ & r & rF/qIr & . & لامبداى ويلكز & زمان*تروه & & \\
\hline
\end{tabular}

در گروه عادى و خودكارآمدى تحصيلى در گروه نارساخوان) به لحاظ

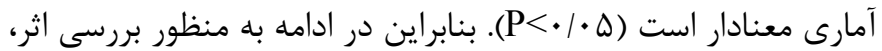
هر يك از اين متغيرها به تفكيك در جدول ه آمدهاند.
مقادير مربوط به تحليل واريانس با اندازه گيرى مكر در جدول † بيانز

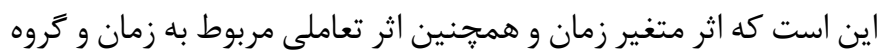

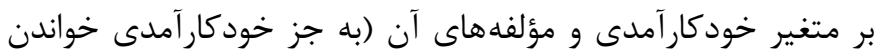

جدول ه. برآورد مقادير آزمون تحليل واريانس با اندازهيرى مكرر جهت مقايسه ميانكَين متغير خودكارآمدى و مؤلفه هاى آن در مراحل سه كانه در كروههاى مورد مطالعه

\begin{tabular}{|c|c|c|c|c|c|c|c|c|}
\hline حجم اثر & $\mathbf{P}$ & $\mathbf{F}$ & مجذانگين & درازيه & مجذورات & منبع & متغير & كروه \\
\hline . MFT & $\cdot / \cdots$ & $99 / r V I$ & $\Delta \cdot V / \cdot q \cdot$ & r & $1 . \mid f / 1 V$ & مراحل & \multirow{3}{*}{ خودكار آمدى عمومى } & \multirow{12}{*}{ عادى } \\
\hline$\cdot \mid \Lambda \ldots$ &.$/ \cdots$ & $99 / 1 \ldots$ & $V \cdot r / F V F$ & $r$ & $\mid f \cdot F / q 4 q$ & گروه**مراحل & & \\
\hline$\cdot / 1 \wedge$ & $\cdot|\cdot r|$ & $\Delta / T V I$ & IIEq/rAr & 1 & $1199 / r \wedge r$ & تروه & & \\
\hline שחז/. & $\cdot / \cdot r$ & $V / r \cdot V$ & $r F / \cdot I r$ & $r$ & $\mathrm{FN} / \mathrm{TQ}$ & مراحل & \multirow{3}{*}{ خود كار آمدى } & \\
\hline - ITFq & $\cdot / \cdot 1$ & V/qFV & $r \varepsilon / 110$ & r & $\Delta T / T M I$ & كروهُ*مراحل & & \\
\hline$\cdot / \Lambda \gamma$. & $\cdot / \cdots$ & N/৭६^ & $V \varepsilon / \cdot \cdot \Delta$ & 1 & $V \varepsilon / \cdot \cdot \Delta$ & كروه & & \\
\hline. $\mid 191$ & $\cdot|\cdot \Delta|$ & $F / \Delta q)$ & $9 / 994$ & r & $19 / \Gamma \wedge \Delta$ & مراحل & \multirow{3}{*}{ خود كار آمدى } & \\
\hline$\cdot / 1 \Delta$ & $\cdot / \cdot \Delta r$ & $F / T \Delta I$ & N/qVF & r & $1 V / q \& q$ & حروهِ*مراحل & & \\
\hline$\cdot / \cdot v \Delta$ & $\cdot / I V V$ & 1/949 & $r|/ \Delta \Delta|$ & 1 & $T I / \Delta \Delta \mid$ & كروه & & \\
\hline - MFET & $\cdot / \cdots$ & IV/QTR & $\forall \& / 19 V$ & r & אח & مراحل & \multirow{3}{*}{ مهارت هاى اجتماعى } & \\
\hline$\cdot|F \Delta|$ & $\cdot / \cdots$ & 19/VIr & DI/9सG & r & I.r/AVT & كروه**مراحل & & \\
\hline$\cdot / T r$. & $.1 \cdot 19$ & GIVET & س & 1 & $|r||\cdot| r$ & كروه & & \\
\hline
\end{tabular}




\begin{tabular}{|c|c|c|c|c|c|c|c|c|}
\hline حجم اثر & $\mathbf{P}$ & $\mathbf{F}$ & مجذوراتين & آزادجى & مجذورات & منبع & متغير & كروه \\
\hline . rut & $\cdot / \ldots$ & $|F / A T|$ & GY/QYF & r & $1 r \Delta / q r q$ & مراحل & \multirow{3}{*}{ هيجانى هاى } & \multirow{3}{*}{ عادى } \\
\hline . IDSF & $\cdot \cdots$ & $r 1 / \cdot v q$ & $|r T / \cdot \Delta|$ & $r$ & $r g q / l \cdot r$ & تروه*مراحل & & \\
\hline$\cdot \pi r r$ & $.1 \cdot .1$ & $|F /| \Lambda \Lambda$ & $r V \Delta / \Delta \Delta I$ & 1 & $r V \Delta / \Delta \Delta I$ & كروه & & \\
\hline • NIr & $\cdot 1 \cdot$ & $\Delta q / v \Delta$. & $1119 / v r$ & r & rrrq/4G & مر احل & \multirow{3}{*}{ خودكار آمدى } & \multirow{15}{*}{ نارساخوان } \\
\hline - MAT & $\cdot / \ldots$ & $99 / \cdot r T$ & $\mid r q r / \Delta \ldots$ & r & $r \Delta \wedge \vee / \cdots$ & تروه**مراحل & & \\
\hline . $/ \Delta T A$ & $\cdot / \cdots$ & reIAVE & $F \wedge \cdot \mid / \Lambda \notin \varepsilon$ & 1 & 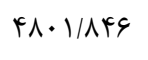 & كروه & & \\
\hline $.1 .9 \mathrm{~V}$ & $\cdot 1 \cdot \Delta V$ & $|r /| \Lambda \varphi$ & $r \varepsilon \mid \cdot \Delta 1$ & r & $V T / I \cdot r$ & مراحل & \multirow{3}{*}{ خود تحصيلى آمدى } & \\
\hline$\cdot / \cdot 1 \Delta$ & .1 .94 & V/g4a & Tr/g/Q & $r$ & FA/TrI & تروه*مراحل & & \\
\hline$\cdot 1 \cdot v 9$ &.$/ 19 \Delta$ & $r / \cdot \Delta \cdot$ & $\forall \& / 1 \Delta F$ & 1 & $F \varepsilon / 1 \Delta F$ & تروه & & \\
\hline . MAT & $\cdot 1 \cdots$ & $1 \cdot 19 \cdot 9$ & $r N \cdot 1 r$ & r & $\Delta q / \cdot r q$ & مر احل & \multirow{3}{*}{ خود خار آمدى } & \\
\hline$\cdot \mid r F \Lambda$ & 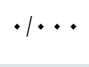 & IT/ATV & $\varphi \&|\Delta Q|$ & r & $9 r / 1 \cdot r$ & تروه*مراحل & & \\
\hline.$/ 195$ & $\cdot \cdot \cdot T \Delta$ & $\Delta / V \cdot V$ & IrN|G9V & 1 & IrN/G\&V & تروه & & \\
\hline - $/$ QTY & $\cdot 1 \cdots$ & TE/TYSQ & $15 \cdot 199 \mathrm{~V}$ & r & Tצו/Tr & مراحل & \multirow{3}{*}{ مهارت هاى اجتماعى } & \\
\hline - MFt & $\cdot / \cdots$ & IN/QAF & $q F / D / T$ & $r$ & $\mid \wedge q / . ५ \&$ & كروه*مراحل & & \\
\hline$\cdot \mid \Delta F Y$ & $\cdot 1 \cdots$ & TN/GEV & $\Delta F F / \cdot \Delta l$ & 1 & $\Delta f F / \cdot \Delta l$ & كروه & & \\
\hline$\cdot|\Delta \wedge|$ & $\cdot \cdots$ & $r r / 999$ & $19 \cdot / 9 \mathrm{VF}$ & r & $r \wedge 1 / q \uparrow q$ & مر احل & \multirow{3}{*}{ واكنش هاى } & \\
\hline. $\mid G Y F$ & $\cdot / \cdots$ & $r q / 91 r$ & TYF/T.D & r & $|F| N / F \mid$ & كروه*مراحل & & \\
\hline .19 .9 & $\cdot / \ldots$ & $r V / r \Delta V$ & $V \Delta \cdot|A T|$ & 1 & $V \Delta \cdot|A Y|$ & كروه & & \\
\hline
\end{tabular}

ميانگين متغير خودكارآمدى و مؤلفه هاى آن (به جز خودكارآمدى

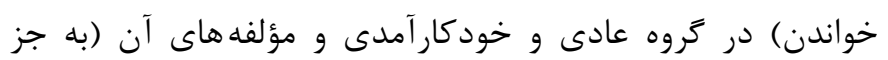

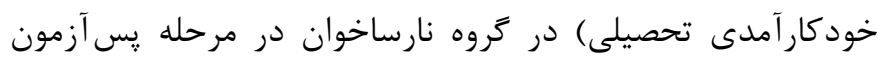

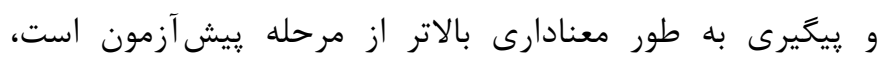

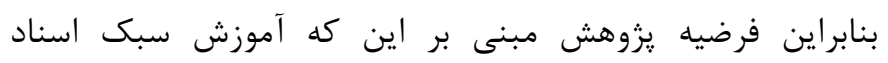

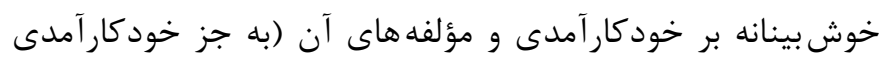

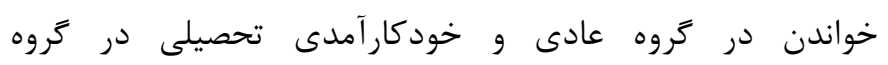

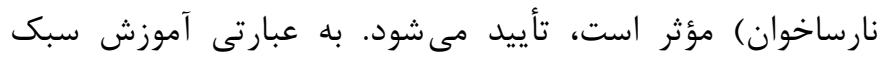

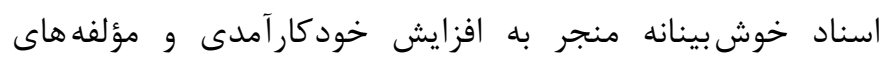

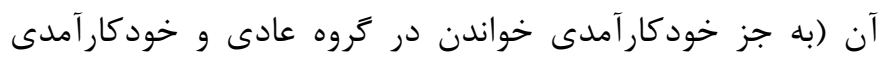
تحصيلى در گروه نارساخوان) گرديده و اين اثر در طول زمان حفظ
برآورد مقادير آزمون تحليل واريانس در جدول ه نشاندهنده اين

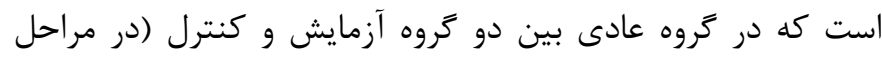

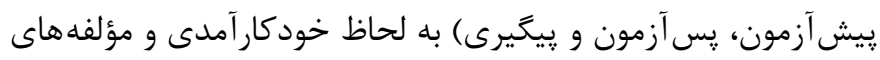

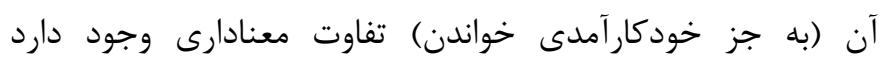

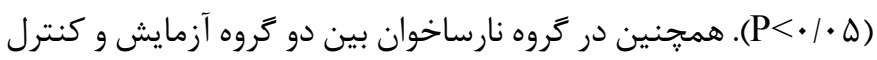

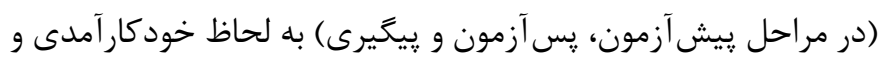

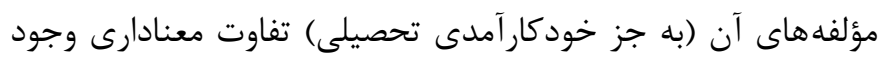

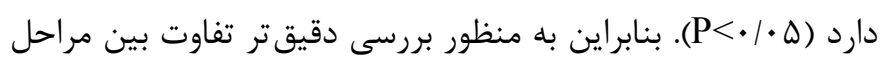

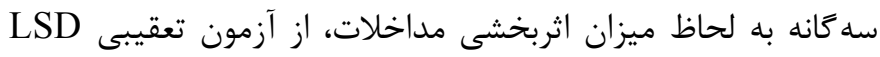

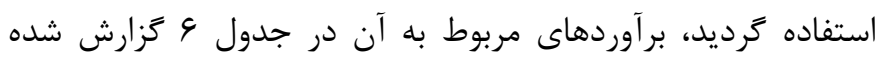
بر حسب مقادير مربوط به آزمون تعقيبى LSD در جدول 4 
جدول 9. نتايج آزمون تعقيبى LSD براى مقايسه ميانگين نمرات خودكارآمدى و مؤلفه هاى آن در مراحل سه كانه در گروههاى مورد مطالعه

\begin{tabular}{|c|c|c|c|c|c|c|c|}
\hline $\mathbf{P}$ & 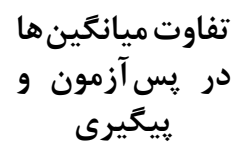 & $\mathbf{P}$ & 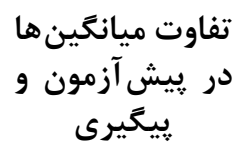 & $\mathbf{P}$ & دقاوت ميش & متغير & كروه \\
\hline .1111 & $1 / \mu_{\Lambda}$ & $\cdot / \cdots$ & $-V / \cdot V V$ & $\cdot / \cdots$ & $-\Lambda / 11 \Delta$ & خودكار آمدى عمومى & \multirow{5}{*}{ عادى } \\
\hline . $\mid$ RTI &. $\mid 910$ &.$/ . T G$ & $-1 / r 99$ &.$/ .1$ & $-1 / \wedge \wedge \Delta$ & خودكار آمدى تحصيلى & \\
\hline • $/ \Delta T V$ & וTוא. & $\cdot / \cdot V q$ & -./9Tr & $\cdot \mid \cdot \Delta 1$ & $-1 / / \Delta F$ & خود كار آمدى خواندن & \\
\hline$\cdot / \mu \cdot r$ & - MKE & $\cdot / \cdots$ & $-T / 110$ & $\cdot \cdots$ & $-Y / Y \& T$ & مهارت هاى اجتماعى & \\
\hline . /VTr &.$- / 1 \Delta F$ & $\cdot 1 \cdot$ & $-Y / V \& Q$ & $.1 \cdot 1$ & $-r / 9 \mid \Delta$ & واكنش هاى هيجانى & \\
\hline$\cdot$ - VAAV &.$/ 195$ & $\cdot / \cdots$ & $-11 / 199$ & $\cdot / \cdot$ & $-11 / 4 a r$ & خودكار آمدى عمومى & \multirow{5}{*}{ 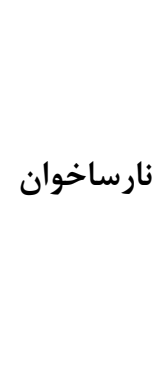 } \\
\hline - $/ \Lambda \Delta T$ & $-\cdot / \cdot V V$ & $\cdot|\cdot \Delta|$ & $-Y / \cdot V V$ & $\cdot|\cdot \Delta|$ & $-r / \cdots$ & خودكار آمدى تحصيلى & \\
\hline$\cdot|r F|$ & $-\cdot 10 \cdot$ & $\cdot \cdots$ & $-r / \cdot r \Lambda$ &.$/$ & 吾 & خودكار آمدى خواندن & \\
\hline$\cdot / r \wedge 9$ & .1910 & $\cdot 1 \cdot \cdots$ & - & $\cdot / \cdots$ & $-F / / \Delta F$ & مهارت هاى اجتماعى & \\
\hline$\cdot \operatorname{lnTH}$ & $\cdot / l \Delta f$ & $\cdot / \cdots$ & $-F / 910$ & $\cdot / \cdots$ & $-F / V \varphi \Delta$ & واكنش هاى هيجانى & \\
\hline
\end{tabular}

سبك اسناد خوشبينانه اشاره دارد كه در يروتكل مورد استفاده اين

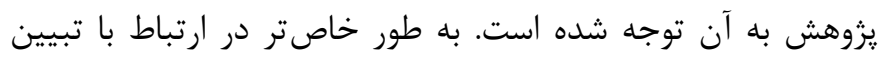

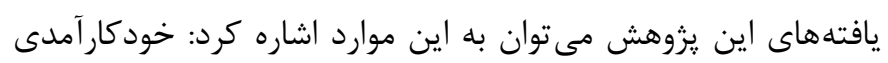

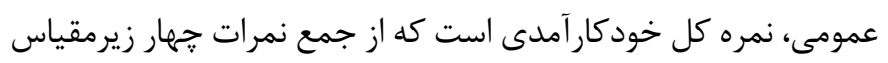

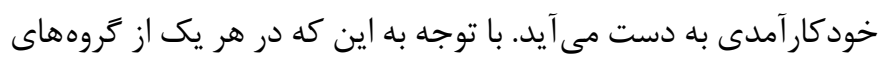

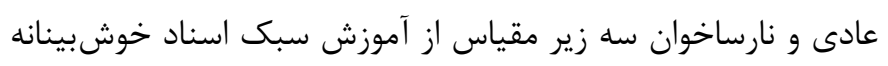

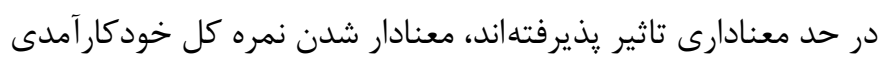

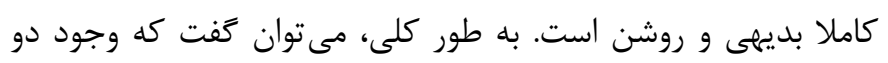
مهارت حل مسئله و جراتمندى در يروتكل مورد استفاده، تاثير مداخله

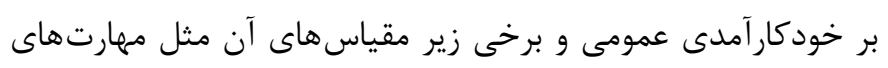

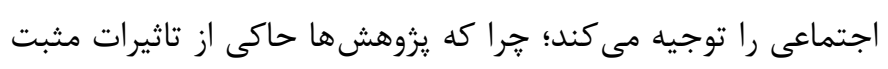

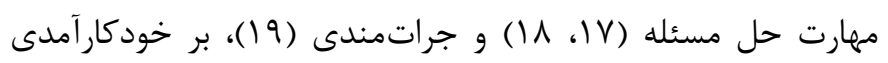

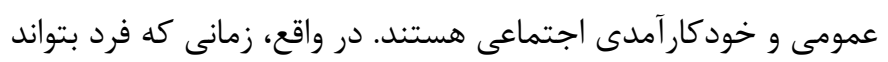
مسائل متعدد را به درستى تعريف كند و و با كمكى بارش ذارد ذهنى راهي حل هاى مناسبى براى آنها تدارك ببيند كه منجر به حل مسائلش شود، تصن

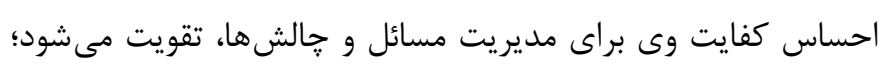

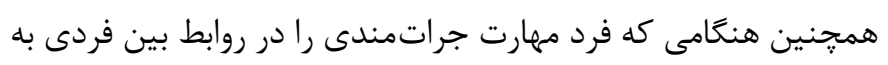

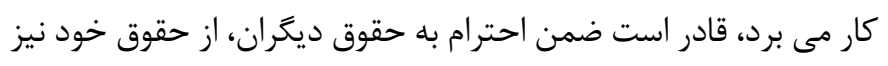

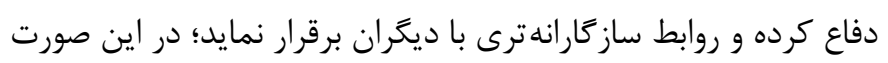

يزروهش حاضر با هدف بررسى تاثير آموزش سبك اسناد خوشبينانه

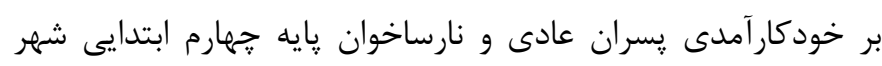

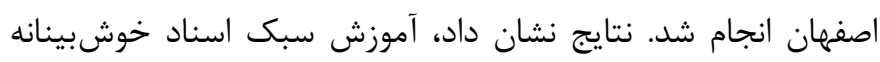

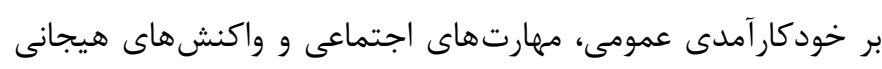

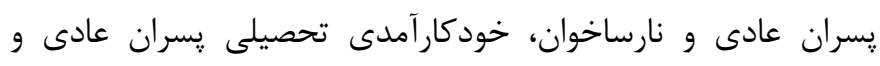

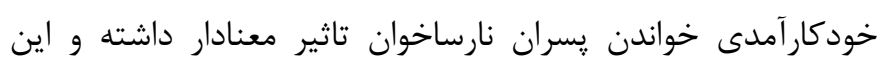

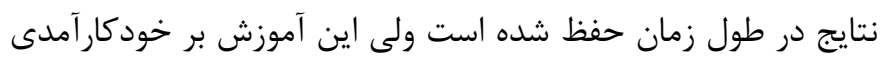

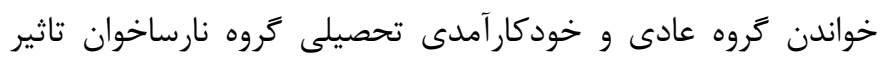

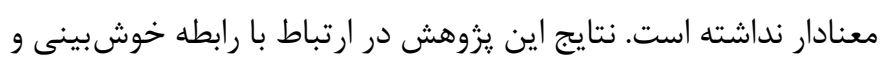

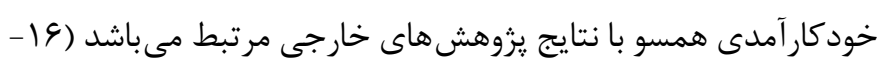

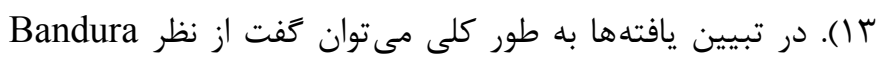

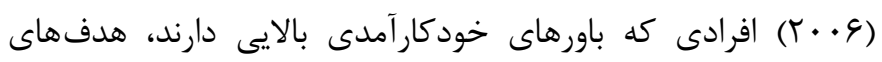

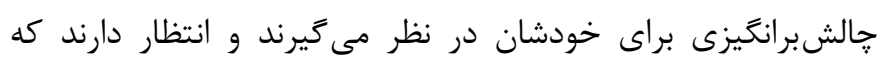

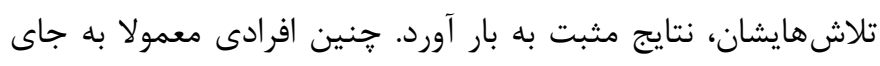

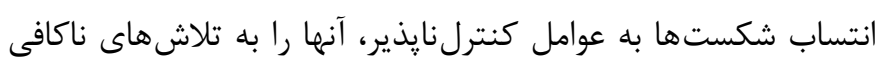

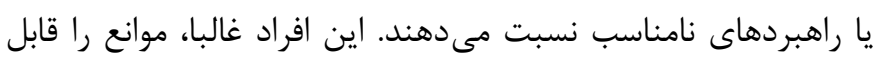

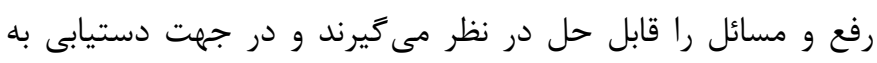

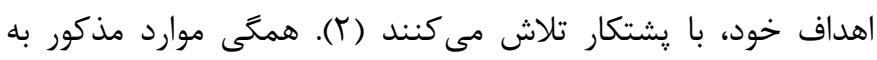


ضعيف عمل كردن در برخى حيطههاى تحصيلى قادر به برآوردن

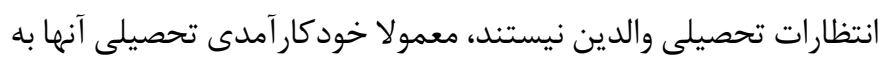

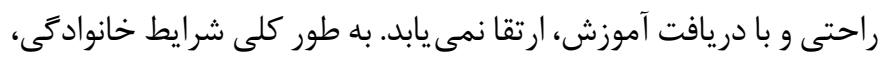

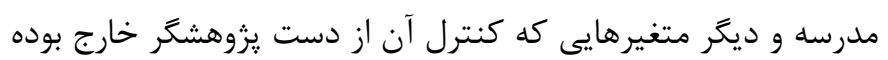

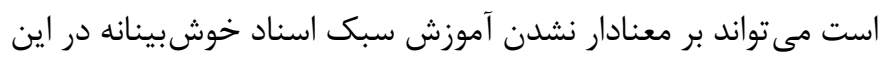

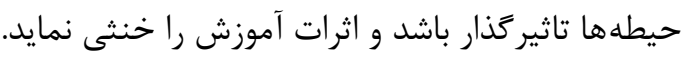

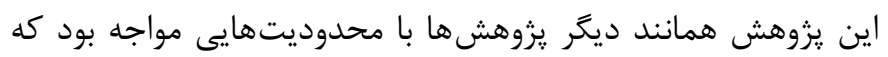
بايد مورد توجه قرار گيرد. از جمله محدوديتهاى اين مطالعه مىتوان به محدود بودن نمونه يزوهش به جنسيت مذكر، عدم حضور ديكر

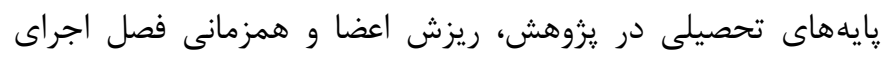

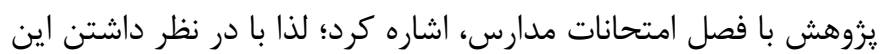

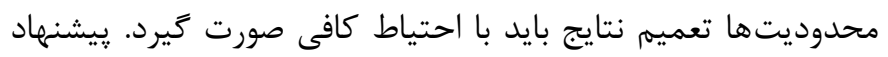

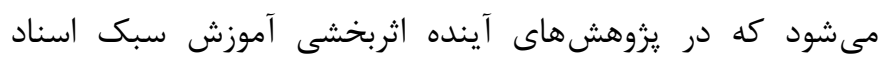

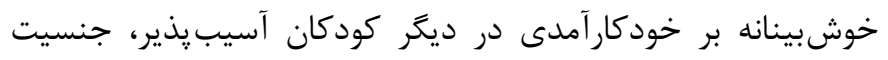

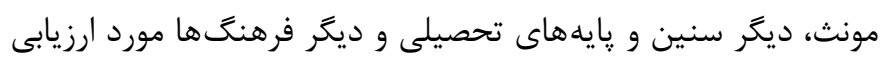

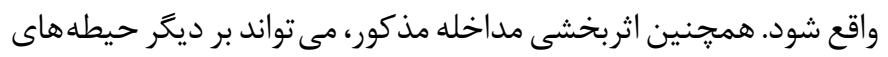

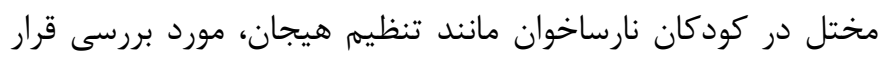

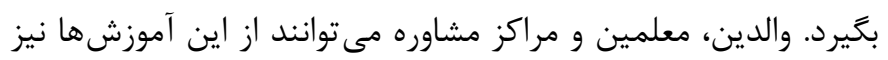

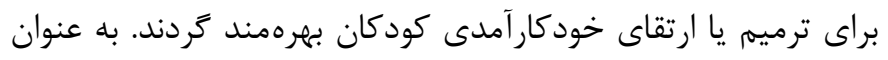

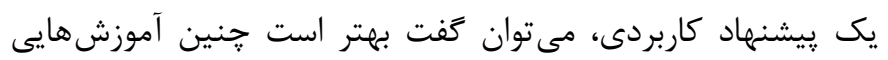

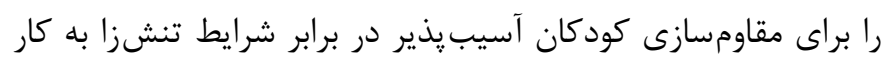

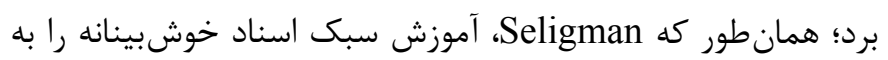
عنوان يك برنامه بيشخيرانه براى مقاوم ساختن كودكان در برابر ابتلا به إنه

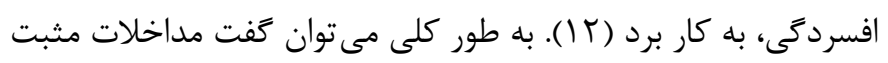

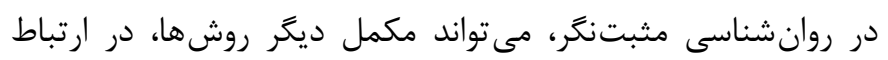

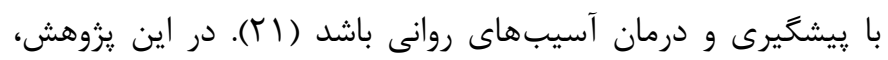

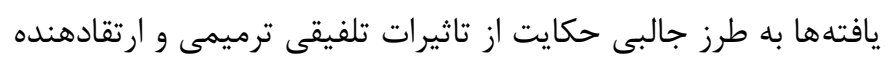

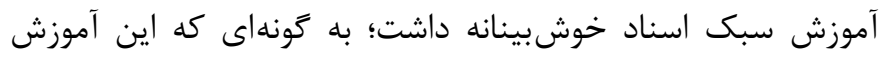

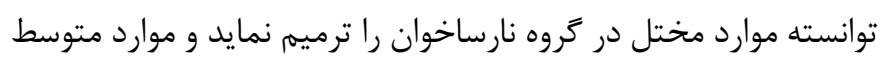

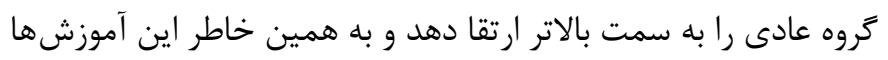

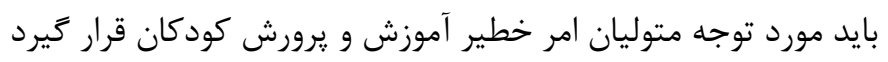

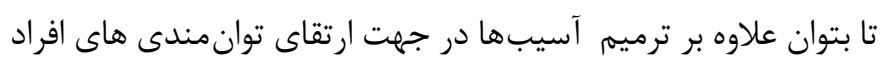

جامعه كام برداشت.

\section{نتيجه گيرى}

با توجه به نتايج يزوهش حاضر، مى توان نتيجه كيرى نمود كه با اصلاح

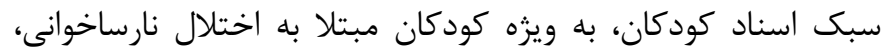

فرد از جانب ديخران همم مورد احترام واقع مىشود و ضمن يرورش عزت

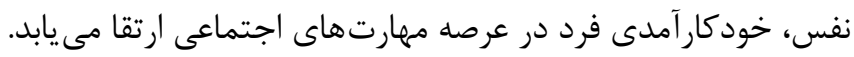

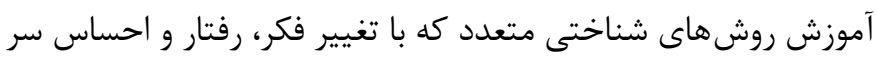

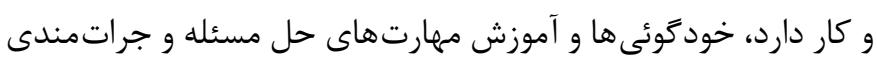

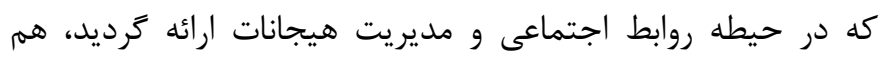

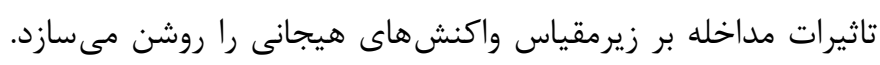
به علاوه با توجه به رابطه مثبت سبك اسناد خوش بينانه و شادكامى

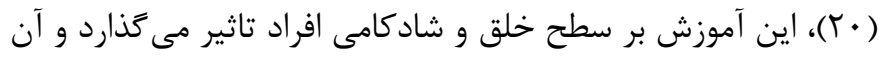
را ارتقا مىدهد، جراكه داشتن انتظارات مثبت نسبت به آينده باعث

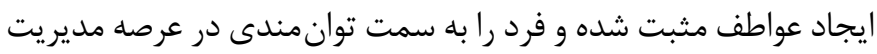
هيجانات سوق مى دهد.

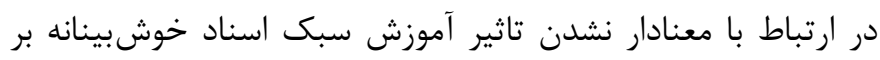

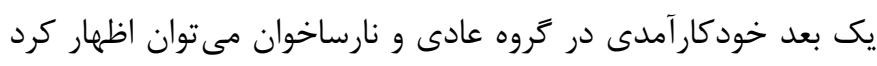

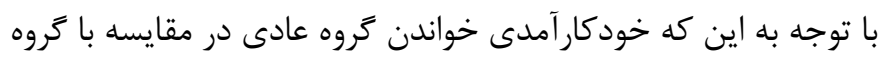

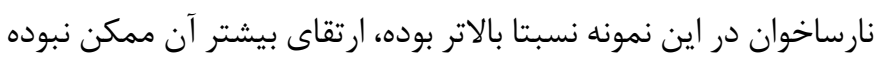

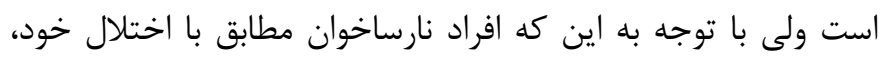

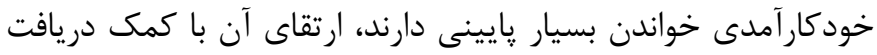

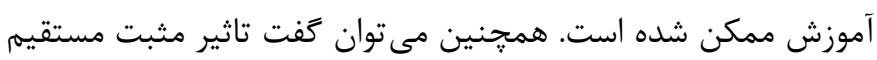
خوشبينى بر توانايى هاى شناختى مثل توجه (ب)، توانايى خواندن و به اله

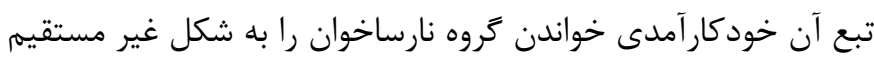

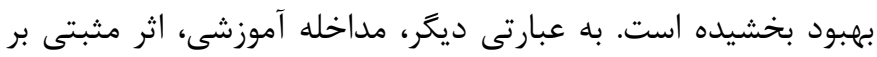

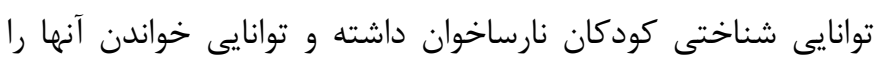

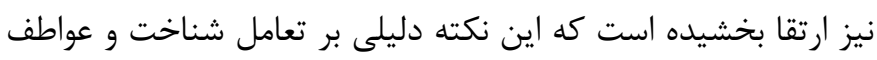

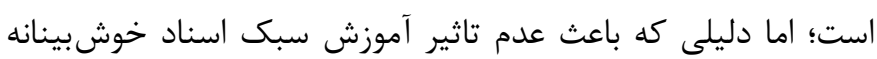

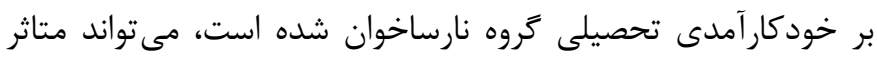

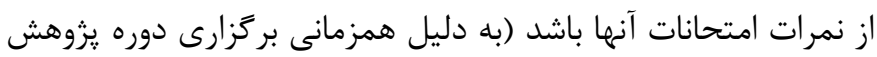

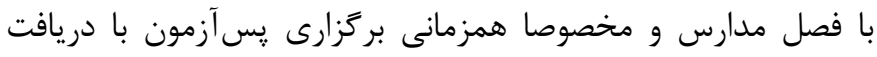

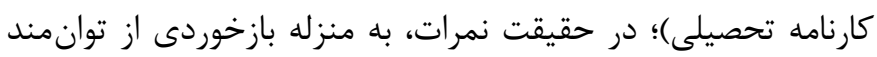

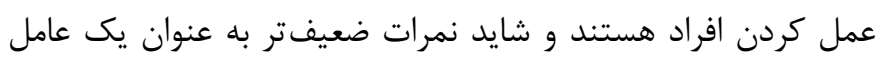

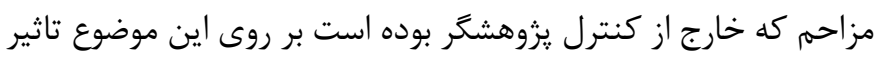

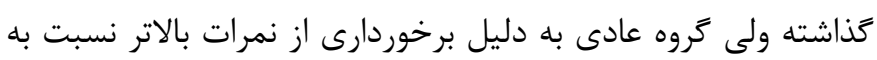

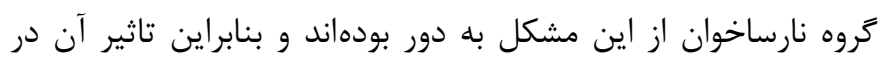

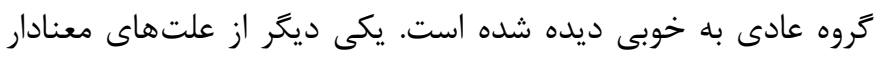
نشدن آموزش سبك اسناد خوشبينانه بر خودكارآمدى تحصيلى گروه

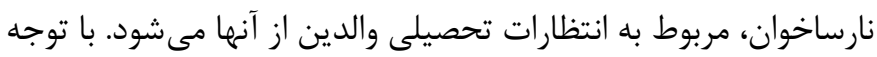
به اين كه زيرمقياس خودكارآهدى تحصيلى، انتظارات تحصيلى والدين

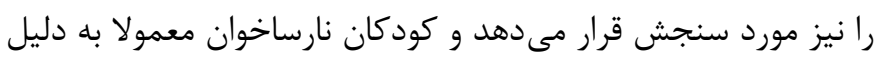




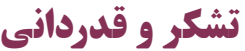

اين مقاله، برگرفته از يايان نامه كارشناسى ارشد روانشناسى بالينى دانشگاه اصفهان است. بدين وسيله از تمامى دبيران و دانش آموزان ناحيه r اصفهان كه در انجام اين يزوهش يارى كردند، تشكر و قدردانى مى شود.

\section{References}

1. Bandura A. Social foundations of thought and action: A social cognitive theory. Englewood Cliffs, NJ:Prentice-Hall;1986.

2. Bandura A. Adolescent development from an agentic perspective. In Pajares F, Urdan T, editors. Self-efficacy beliefs of adolescents. Greenwich, CT:Information Age;2006. pp. 1-43.

3. Schultz DP, Schultz SE. Theories of personality. Seyed Mohammadi Y, Trans. Tehran:Virayesh Press;2013. (Persian)

4. Tanaka H, Black JM, Hulme C, Stanley LM, Kesler SR, Whitfield-Gabrieli S, et al. The brain basis of the phonological deficit in dyslexia is independent of IQ. Psychological Science. 2011;22(11):1442-1451.

5. Ganji M. Psychological pathology based on DSM-5. Vol 2. Tehran:Savalan Press;2015. (Persian)

6. Kormi Nouri R, Moradi AR, Akbari Zardkhaneh S, Zahedian H. Reading and dyslexia test. Tehran:Tarbiat Moalem Press;2008. (Persian)

7. Pahlavan-Neshan S, Pourmohammadreza-Tajrishi MS, Sajedi F, Shokri O. The effect of psychological immunization program on pessimistic attribution style of boy students with dyslexia. Archives of Rehabilitation. 2014;15(3):52-63. (Persian)

8. Ben-Naim S, Laslo-Roth R, Einav M, Biran H, Margalit M. Academic self-efficacy, sense of coherence, hope and tiredness among college students with learning disabilities. European Journal of Special Needs Education. 2017;32(1):18-34.

9. Seyed S, Salmani M, Motahari Nezhad F, Noruzi R. Self-efficacy, achievement motivation, and academic progress of students with learning disabilities: A comparison with typical students. Middle East Journal of Rehabilitation and Health. 2017;4(2):e44558.

10. Hen M, Goroshit M. Academic procrastination, emotional

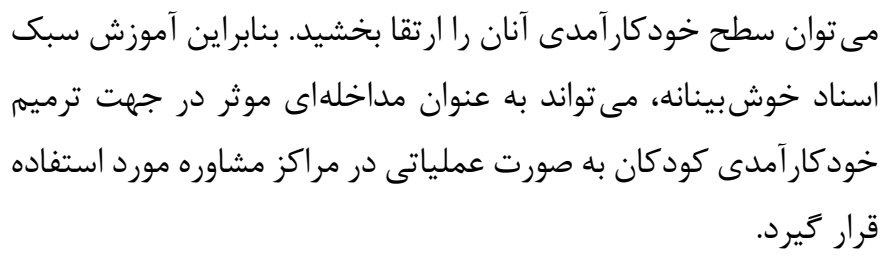

intelligence, academic self-efficacy, and GPA: A comparison between students with and without learning disabilities. Journal of Learning Disabilities. 2014;47(2):116-124.

11. Yuksel M, Okan N, Eminoglu Z, Akca-Koca D. The mediating role of self-efficacy and hope on primary school students' social-emotional learning and primary mental abilities. Universal Journal of Educational Research. 2019;7(3):729-738.

12. Seligman MEP. The optimistic child. Davarpanah F, Trans. Tehran:Roshd;2016. (Persian)

13. Phan HP. Longitudinal examination of optimism, personal self-efficacy and student well-being: A path analysis. Social Psychology of Education. 2016;19(2):403-426.

14. Feldman DB, Kubota M. Hope, self-efficacy, optimism, and academic achievement: Distinguishing constructs and levels of specificity in predicting college grade-point average. Learning and Individual Differences. 2015;37:210-216.

15. Posadzki P, Stockl A, Musonda P, Tsouroufli M. A mixed-method approach to sense of coherence, health behaviors, self-efficacy and optimism: Towards the operationalization of positive health attitudes. Scandinavian Journal of Psychology. 2010;51(3):246-252.

16. Karademas EC, Kafetsios K, Sideridis GD. Optimism, self-efficacy and information processing of threat-and well-being-related stimuli. Stress and Health: Journal of the International Society for the Investigation of Stress. 2007;23(5):285294.

17. Erozkan A. The effect of communication skills and interpersonal problem solving skills on social self-efficacy. Educational Sciences: Theory and Practice. 2013;13(2):739-745.

18. Bilgin M, Akkapulu E. Some variables predicting social 
self-efficacy expectation. Social Behavior and Personality: An International Journal. 2007;35(6):777-788.

19. Akbari B, Moosavi SM, Asli SA. Comparison of the effect of cognitive strategies and assertiveness training on general self-efficacy of female students. Research in Medical Education. 2015;7(3):40-48. (Persian)

20. Veronese G, Castiglioni M, Tombolani M, Said M. 'My happiness is the refugee camp, my future Palestine': Optimism, life satisfaction and perceived happiness in a group of Palestinian children. Scandinavian Journal of Caring Sciences. 2012;26(3):467-473.

21. Lee Duckworth A, Steen TA, Seligman MEP. Positive psychology in clinical practice. Annual Review of Clinical Psychology. 2005;1(1):629-651.

22. Kormi-Nouri R, Moradi A. Reading and dyslexia test. Tehran:Jahaddaneshgahi (Tarbiat Moalem);2005. (Persian)

23. Bazrafshan Moghadam A. Examination of Prevalence of dyslexia reading and writing between the second and third grade of secondary school girls and boys in Mashhad. [MA Thesis]. Tehran:University of Tehran;1997. (Persian)

24. Pakdamansavoji A. The effect of metacognitive strategies on comprehension of students with reading problem [MSc Thesis]. Tehran:University of Tehran;2000. (Persian)

25. Lahijanian Z. Effectiveness of cognitive-behavioral therapy on self-perception among gifted students with learning disabilities [MA Thesis]. Isfahan:University of Isfahan;2010. (Persian) 26. Seligman ME, Kaslow NJ, Alloy LB, Peterson C, Tanenbaum RL, Abramson LY. Attributional style and depressive symptoms among children. Journal of Abnormal Psychology. 1984:93(2):235-238.

27. Nolen-Hoeksema S, Girgus JS, Seligman ME. Learned helplessness in children: A longitudinal study of depression, achievement, and explanatory style. Journal of Personality and Social Psychology. 1986;51(2):435-442.

28. Dorostkar N, Javadi MJ, Sepah Mansour M. The relationship between attribution styles and students' perceptions of parents' parenting styles with their academic achievement. Psychological Researchs, 2012;4(14):25-41. (Persian)

29. Shahni Yailagh M, Jalilzadeh N, Maktabi GH. The relationships between attributional style, depression and school performance in fifth-grade female primary school students in Ahwaz. Journal of Educational Psychology Studies, 2010;7(12):47-70. (Persian)

30. Latifi Z, Esteki-Azad N. The effectiveness of behavioral strategies training on social, academic, reading and emotional self-efficacy in students with learning disabilities. Quarterly Journal of Applied Research in Educational Psychology. 2015;2(1):80-97. (Persian) 